Article

\title{
Effect of Pt Promotion on the Ni-Catalyzed Deoxygenation of Tristearin to Fuel-Like Hydrocarbons
}

\author{
Ryan Loe ${ }^{1,2}$, Kelsey Huff ${ }^{1}$, Morgan Walli ${ }^{1}$, Tonya Morgan ${ }^{1}$, Dali Qian ${ }^{1}$, Robert Pace ${ }^{1,2}$, \\ Yang Song 1,2, Mark Isaacs ${ }^{3,4} \mathbb{D}$, Eduardo Santillan-Jimenez ${ }^{1} \mathbb{D}$ and Mark Crocker ${ }^{1,2, *(\mathbb{D})}$ \\ 1 Center for Applied Energy Research, University of Kentucky, 2540 Research Park Drive, Lexington, \\ KY 40511, USA; ryan.loe@uky.edu (R.L.); kelsey.huff@uky.edu (K.H.); morgan.walli@uky.edu (M.W.); \\ tonya.morgan@uky.edu (T.M.); dali.qian@uky.edu (D.Q.); robert.pace@uky.edu (R.P.); \\ vanessa.song@uky.edu (Y.S.); esant3@uky.edu (E.S.-J.) \\ 2 Department of Chemistry, University of Kentucky, Lexington, KY 40506, USA \\ 3 Harwell XPS, Research Complex at Harwell (RCaH), Rutherford Appleton Laboratory, Harwell Oxford, \\ Didcot OX11 0FA, UK; mark.isaacs@ucl.ac.uk \\ 4 Department of Chemistry, University College London, 20 Gordon St, Kings Cross, London WC1H 0AJ, UK \\ * Correspondence: mark.crocker@uky.edu; Tel.: +1-859-257-0295
}

Received: 31 January 2019; Accepted: 20 February 2019; Published: 22 February 2019

\begin{abstract}
Pt represents an effective promoter of supported Ni catalysts in the transformation of tristearin to green diesel via decarbonylation/decarboxylation $\left(\mathrm{deCO}_{\mathrm{x}}\right)$, conversion increasing from $2 \%$ over $20 \% \mathrm{Ni} / \mathrm{Al}_{2} \mathrm{O}_{3}$ to $100 \%$ over $20 \% \mathrm{Ni}-0.5 \% \mathrm{Pt} / \mathrm{Al}_{2} \mathrm{O}_{3}$ at $260{ }^{\circ} \mathrm{C}$. Catalyst characterization reveals that the superior activity of $\mathrm{Ni}-\mathrm{Pt}$ relative to $\mathrm{Ni}$-only catalysts is not a result of $\mathrm{Ni}$ particle size effects or surface area differences, but rather stems from several other phenomena, including the improved reducibility of $\mathrm{NiO}$ when $\mathrm{Pt}$ is present. Indeed, the addition of a small amount of $\mathrm{Pt}$ to the supported Ni catalyst dramatically increases the amount of reduced surface metal sites, which are believed to be the active sites for $\mathrm{deCO}_{\mathrm{x}}$ reactions. Further, Pt addition curbs the adsorption of $\mathrm{CO}$ on the catalyst surface, which decreases catalyst poisoning by any $\mathrm{CO}$ evolved via decarbonylation, making additional active sites available for deoxygenation reactions and/or preventing catalyst coking. Specifically, $\mathrm{Pt}$ addition weakens the $\mathrm{Ni}-\mathrm{CO}$ bond, lowering the binding strength of $\mathrm{CO}$ on surface Ni sites. Finally, analysis of the spent catalysts recovered from deCO $\mathrm{O}_{\mathrm{x}}$ experiments confirms that the beneficial effect of $\mathrm{Pt}$ on catalyst performance can be partially explained by decreased coking and fouling.
\end{abstract}

Keywords: triglycerides; tristearin; deoxygenation; decarbonylation; decarboxylation; nickel; platinum; hydrocarbons

\section{Introduction}

The limited availability and uneven geographical distribution of fossil resources, as well as environmental concerns associated with their use, demand the development of renewable and carbon neutral alternatives. Biofuels-i.e., fuels derived from biomass - are not only renewable and have the potential to become carbon neutral, but they can avoid competing with the food supply if they are obtained from waste or non-edible feedstocks [1-4]. Biodiesel, which is comprised of fatty acid methyl esters (FAMEs), is currently produced industrially from a variety of oils and fats through the transesterification or esterification of their triglyceride and fatty acid constituents, respectively. Although biodiesel production is technically straightforward, it displays several drawbacks as a fuel (e.g., poor cold flow properties and storage stability) stemming from the oxygen content of 
FAMEs [5,6]. Therefore, catalytic deoxygenation processes are being developed to convert the same feedstocks to fuel-like hydrocarbons that, in addition to being renewable, are also chemically identical (and thus a drop-in alternative) to fossil fuels. Investigations into such processes have revealed two dominant reaction pathways: (1) hydrodeoxygenation (HDO), where oxygen is eliminated as water; and (2) decarbonylation/decarboxylation $\left(\mathrm{deCO}_{\mathrm{x}}\right)$, in which oxygen is removed as $\mathrm{CO}$ or $\mathrm{CO}_{2}$, respectively. The HDO reaction pathway is typically very selective, yielding the desired hydrocarbon products with a good carbon efficiency and saturating the $\mathrm{C}=\mathrm{C}$ double bonds that are abundant in many feed sources. However, this approach requires high $\mathrm{H}_{2}$ pressures and problematic sulfided catalysts that deactivate in the presence of water and risk contaminating the products with sulfur. In contrast, the deCO $\mathrm{x}_{\mathrm{x}}$ pathway yields hydrocarbons containing one less carbon than the original feed, but does so avoiding the use of sulfided catalysts and requiring little to no $\mathrm{H}_{2}$ for oxygen removal [7].

In an effort to identify promising deoxygenation catalysts, Snåre et al. screened a number of active metals on various supports in the deoxygenation of stearic acid, a model fatty acid compound, and found that deoxygenation activity follows the order $\mathrm{Pd}>\mathrm{Pt}>\mathrm{Ni}>\mathrm{Rh}>\mathrm{Ir}>\mathrm{Ru}>\mathrm{Os}$ [8]. Unsurprisingly, the majority of deoxygenation studies since then have focused on the use of the two most active metals, Pd [9-18] and Pt [19-29]. However, in previous work, we demonstrated that supported Ni catalysts provide comparable results to $\mathrm{Pd}$ and $\mathrm{Pt}$ formulations in the deoxygenation of triglycerides [30,31]. Admittedly, the Ni loading required (20 wt.\%) is higher than the loading for precious metal catalysts $(1-5 \mathrm{wt} . \%)$; nevertheless, this is made entirely acceptable by the fact that the cost of $\mathrm{Ni}$ is thousands of times lower than that of $\mathrm{Pt}$ or Pd. Although promising, Ni catalysts are prone to deactivation from coking and typically yield more cracking products than Pd and Pt formulations. Although some cracking may be desirable to improve cold flow properties and produce hydrocarbon fuels that fall within the boiling point range of aviation fuels $\left(150-300{ }^{\circ} \mathrm{C}\right)$ [30], excessive cracking can lead to lower yields of fuel-like products and catalyst deactivation $[7,32]$. In light of this, the development of improved Ni-based catalysts is of significant interest.

Attempts to improve Ni deoxygenation catalysts have examined the use of various supports, metal loadings, reactor types, and reaction conditions, with the conversion of lipids to fuel like-hydrocarbons over Ni-based catalysts being the subject of a recent review by Kordulis [6]. Studies focused on catalyst carriers have shown that metal oxide-supported catalysts can afford conversion and selectivity values comparable to those attained using carbonaceous supports [32-38]. This is made particularly noteworthy by the fact that albeit carbon-supported deCO $\mathrm{O}_{\mathrm{x}}$ catalysts generally show better yields of fuel-like hydrocarbons [39], coke formation represents the main catalyst deactivation pathway [40], which precludes the facile regeneration of carbon-supported catalysts via the combustion of coke deposits as this approach would also destroy a carbonaceous support. In contrast, metal oxide-supported catalysts can be easily regenerated via calcination [33].

Efforts to develop superior Ni-based deCO $\mathrm{C}_{x}$ catalysts have also focused on modifying the active metal phase [32,41-46]. Loe et al. found that the addition of $\mathrm{Cu}$ to an $\mathrm{Ni} / \mathrm{Al}_{2} \mathrm{O}_{3}$ catalyst facilitated $\mathrm{NiO}$ reduction at lower temperatures [32]. This is beneficial not only because $\mathrm{Ni}^{0}$ is believed to be the active phase for deCO $\mathrm{O}_{x}$, but also because the catalyst can be reactivated in the course of deoxygenation reactions, which are typically performed in the presence of $\mathrm{H}_{2}$. Indeed, a continuous flow of $\mathrm{H}_{2}$ supplied in either semi-batch or fixed bed reactors not only reactivates the catalyst by reducing any oxidized surface $\mathrm{Ni}$ sites, but also by removing any $\mathrm{CO}_{x}$ generated during the deCO $\mathrm{O}_{x}$ process that might otherwise act as catalyst poisons [14]. Saliently, Loe et al. demonstrated that a $20 \% \mathrm{Ni}-5 \%$ $\mathrm{Cu} / \mathrm{Al}_{2} \mathrm{O}_{3}$ catalyst can convert model lipid compounds-such as tristearin and stearic acid-near quantitatively [32]. Remarkably, using hydrogen-rich atmospheres and reaction temperatures as low as $260^{\circ} \mathrm{C}$, which are conditions typically favoring the HDO pathway [38,47], deoxygenation was observed to proceed via de $\mathrm{CO}_{\mathrm{x}}$ [42]. The promotion effect displayed by this bimetallic catalyst relative to its Ni-only counterpart was in large part attributed to the ability of $\mathrm{Cu}$ to facilitate the reduction of $\mathrm{Ni}$ at relatively low temperatures. 
The goal of the present study was to examine the promotion of Ni-based deCO $\mathrm{C}_{x}$ catalysts with small amounts $(\leq 0.5 \mathrm{wt} . \%)$ of $\mathrm{Pt}$, a candidate metal promoter due to its ability to dissociatively adsorb $\mathrm{H}_{2}$, resulting in the spillover of atomic $\mathrm{H}$ onto surrounding metal sites through surface migration [48]. Since $\mathrm{Pt}$ reduces at a lower temperature than $\mathrm{Ni}$, similar promotion effects to those observed with $\mathrm{Cu}$ can be expected. In addition, $\mathrm{Pt}$ can also lower the binding energy of $\mathrm{CO}$ to $\mathrm{Ni}$ in its close proximity [49], which could increase deCO $\mathrm{O}_{x}$ activity by curbing the adsorption of $\mathrm{CO}$ on $\mathrm{Ni}$ sites.

\section{Results and Discussion}

\subsection{Catalyst Characterization}

Catalysts were prepared corresponding to $20 \mathrm{wt} . \% \mathrm{Ni} / \mathrm{Al}_{2} \mathrm{O}_{3}$ promoted with $0,0.1,0.25$, and $0.5 \mathrm{wt} . \% \mathrm{Pt}$. In addition, $0.5 \% \mathrm{Pt} / \mathrm{Al}_{2} \mathrm{O}_{3}$ was prepared as a reference. The $\mathrm{X}$-ray diffractograms in Figure 1 show that all of the as-prepared Ni-containing catalysts presented diffraction peaks at 37.2, $43.4,63.1,75.5$, and $79.4^{\circ}$, which points to the presence of $\mathrm{NiO}$ [50].

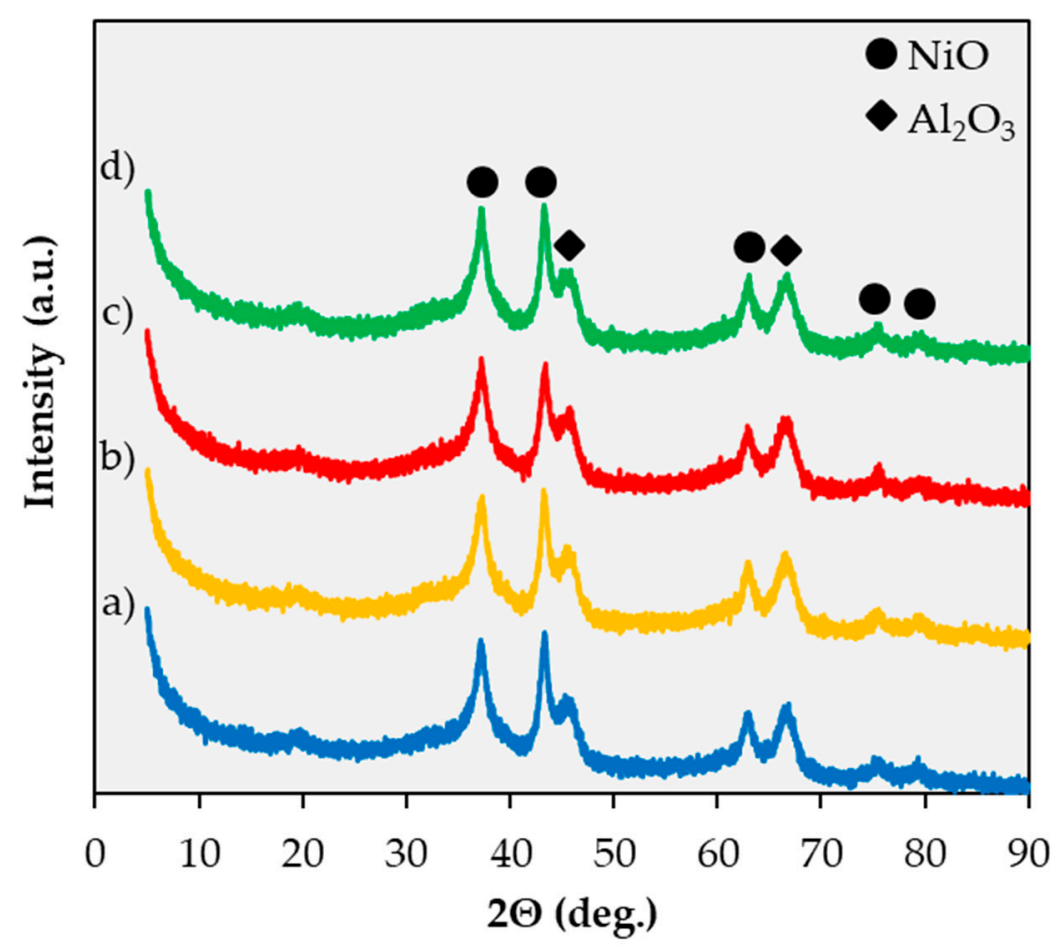

Figure 1. $X$-ray diffraction patterns for $20 \% \mathrm{Ni} / \mathrm{Al}_{2} \mathrm{O}_{3}$ (a), $20 \% \mathrm{Ni}-0.1 \% \mathrm{Pt} / \mathrm{Al}_{2} \mathrm{O}_{3}$ (b), $20 \% \mathrm{Ni}-0.25 \%$ $\mathrm{Pt} / \mathrm{Al}_{2} \mathrm{O}_{3}$ (c), and $20 \% \mathrm{Ni}-0.5 \% \mathrm{Pt} / \mathrm{Al}_{2} \mathrm{O}_{3}(\mathbf{d})$.

Unsurprisingly, Pt peaks are not observed due to the very low Pt metal loadings. The NiO particle sizes were obtained by applying the Scherrer equation to the $37.2^{\circ} \mathrm{NiO}$ peak, and the calculated particle sizes, as well as other textural properties, are listed in Table 1.

The NiO particle size of the bimetallic catalysts was similar to that of the Ni-only catalyst, indicating that the additional calcination step used during Pt addition (see Section 3.1) did not result in sintering of the $\mathrm{NiO}$ to form larger particles. As expected, the surface areas of $20 \% \mathrm{Ni} / \mathrm{Al}_{2} \mathrm{O}_{3}$ and the Ni-Pt bimetallic catalysts are also similar $\left(129-138 \mathrm{~m}^{2} / \mathrm{g}\right)$, and the $0.5 \% \mathrm{Pt} / \mathrm{Al}_{2} \mathrm{O}_{3}$ catalyst has a higher surface area $\left(196 \mathrm{~m}^{2} / \mathrm{g}\right)$ due to the absence of $\mathrm{Ni}$.

Transmission Electron Microscopy (TEM) measurements and TEM observations coupled with Energy Dispersive X-Ray Spectroscopy (EDS) analyses provided additional information regarding particle size (see Figures 2a and A1 in Appendix A), as well as insights into the composition of individual metal particles (see Figures $2 \mathrm{~b}$ and $\mathrm{A} 2$ in Appendix A) for the $20 \% \mathrm{Ni} / \mathrm{Al}_{2} \mathrm{O}_{3}$ and the $20 \%$ $\mathrm{Ni}-0.5 \% \mathrm{Pt} / \mathrm{Al}_{2} \mathrm{O}_{3}$ catalysts. 
Table 1. Textural properties and metal dispersion of the catalysts studied.

\begin{tabular}{ccccc}
\hline \multirow{2}{*}{ Catalyst } & \multicolumn{3}{c}{$\mathbf{N}_{\mathbf{2}}$ Physisorption } & \\
\cline { 2 - 4 } & $\begin{array}{c}\text { BET Surface } \\
\text { Area }\left(\mathbf{m}^{2} / \mathbf{g}\right)\end{array}$ & $\begin{array}{c}\text { Pore Vol. } \\
\left(\mathbf{c m}^{3} / \mathbf{g}\right)\end{array}$ & $\begin{array}{c}\text { Avg. Pore } \\
\text { Diameter (nm) }\end{array}$ & $\begin{array}{c}\text { Avg. NiO Particle } \\
\text { Size (nm) }\end{array}$ \\
\hline $20 \% \mathrm{Ni} / \mathrm{Al}_{2} \mathrm{O}_{3}$ & 135 & 0.29 & 7.0 & 6.8 \\
$20 \% \mathrm{Ni}-0.1 \% \mathrm{Pt}_{\mathrm{Al}} \mathrm{O}_{3}$ & 129 & 0.27 & 7.0 & 7.4 \\
$20 \% \mathrm{Ni}-0.25 \% \mathrm{Pt} / \mathrm{Al}_{2} \mathrm{O}_{3}$ & 138 & 0.29 & 7.0 & 6.1 \\
$20 \% \mathrm{Ni}-0.5 \% \mathrm{Pt}_{\mathrm{Al}} \mathrm{Al}_{3}$ & 134 & 0.29 & 6.9 & 8.7 \\
$0.5 \% \mathrm{Pt} / \mathrm{Al}_{2} \mathrm{O}_{3}$ & 196 & 0.13 & 4.6 & - \\
\hline
\end{tabular}

a)

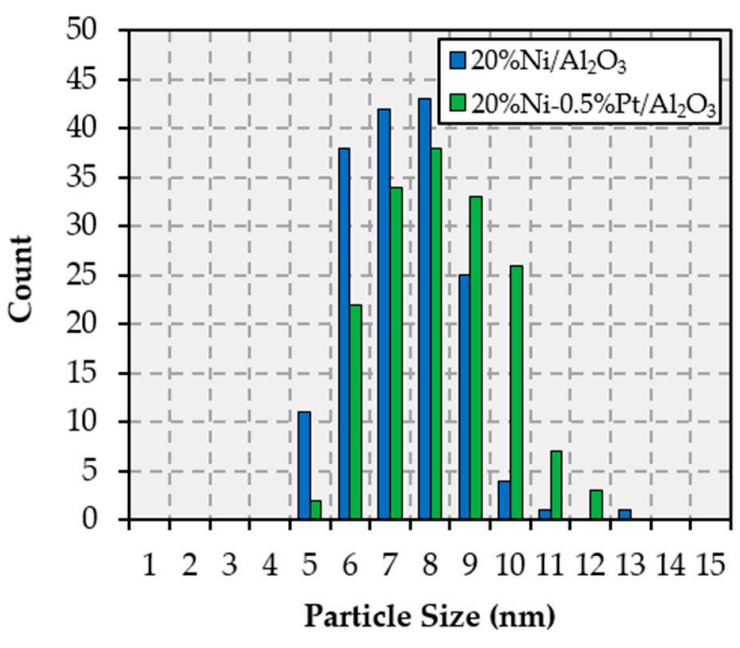

b)

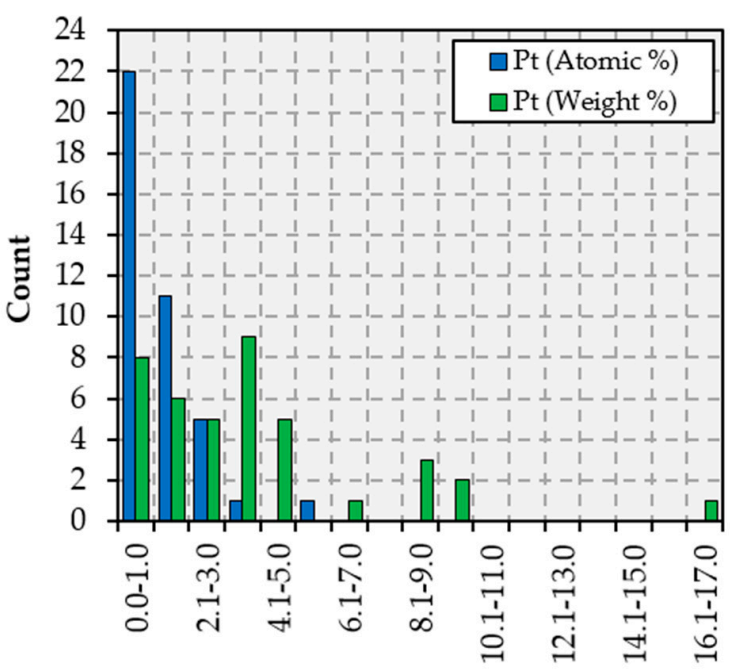

$\mathrm{Pt}$ content of individual metal particles (\%)

Figure 2. Particle size histograms for the $20 \% \mathrm{Ni}-/ \mathrm{Al}_{2} \mathrm{O}_{3}$ and $20 \% \mathrm{Ni}-0.5 \% \mathrm{Pt} / \mathrm{Al}_{2} \mathrm{O}_{3}$ catalysts (a) and metallic composition histograms for the $20 \% \mathrm{Ni}-0.5 \% \mathrm{Pt} / \mathrm{Al}_{2} \mathrm{O}_{3}$ formulation (b).

Notably, both catalysts contain metal particles in a narrow size range, with all particles measured having a diameter between 5 and $13 \mathrm{~nm}$, irrespective of the catalyst. Moreover, as shown in Figure 2a, the vast majority of the metal particles in the monometallic formulation range between 6 and $9 \mathrm{~nm}$, whereas the bimetallic Ni-Pt catalyst contains slightly larger metal particles in the 6 to $10 \mathrm{~nm}$ range. This is in agreement with the average $\mathrm{NiO}$ particle sizes calculated from XRD data (see Table 1), according to which the $20 \% \mathrm{Ni}-0.5 \% \mathrm{Pt} / \mathrm{Al}_{2} \mathrm{O}_{3}$ catalyst exhibited slightly larger particles $(8.7 \mathrm{~nm}$ on average) than the monometallic formulation ( $6.8 \mathrm{~nm}$ on average). The results of the elemental analysis (by EDS) of representative particles in the $20 \% \mathrm{Ni}-0.5 \% \mathrm{Pt} / \mathrm{Al}_{2} \mathrm{O}_{3}$ catalyst - which were used to build the particle composition histogram in Figure $2 b$ - show that the majority of metal particles display a Pt content between 0 and $5 \mathrm{wt} . \%$, which is in line with the $2.4 \mathrm{wt} . \%$ Pt content that would be expected from the bulk metal loading. Interestingly, the elemental maps displayed in Figure A2 in Appendix A show that Pt-rich regions coincide with the location of Ni particles. Moreover, $\mathrm{Pt}$ was present in every single one of the particles analyzed by means of EDS, which suggests that Pt is either alloyed or closely associated with $\mathrm{Ni}$, i.e., likely constituting a bimetallic phase as opposed to two distinct monometallic phases.

The TPR profiles shown in Figure 3 clearly show that $\mathrm{Pt}$ addition changes the reduction temperature of oxidized $\mathrm{Ni}$ species in the catalysts. Indeed, the $20 \% \mathrm{Ni} / \mathrm{Al}_{2} \mathrm{O}_{3}$ catalyst displays a broad reduction event with a maximum at $550{ }^{\circ} \mathrm{C}$ associated with the reduction of $\mathrm{NiO}$ to $\mathrm{Ni}{ }^{0}$ on the $\gamma-\mathrm{Al}_{2} \mathrm{O}_{3}$ support [51]. This broad reduction event has two shoulders, including one with a local maximum at $350{ }^{\circ} \mathrm{C}$ attributed to the reduction of larger $\mathrm{NiO}$ particles that interact weakly with the support [51], and another above $600{ }^{\circ} \mathrm{C}$ assigned to the reduction of $\mathrm{NiAl}_{2} \mathrm{O}_{4}$ [32]. The Pt-containing catalysts also 
exhibit the same reduction events, with the first - occurring between 300 and $350{ }^{\circ} \mathrm{C}$ - being most likely associated with the reduction of large Ni ensembles either alloyed or in close proximity to $\mathrm{Pt}$ [49], and the broad peak above $500{ }^{\circ} \mathrm{C}$ with a high temperature $\left(\geq 700^{\circ} \mathrm{C}\right)$ shoulder being assigned to the reduction of $\mathrm{NiO}$ particles and $\mathrm{NiAl}_{2} \mathrm{O}_{4}$, respectively.

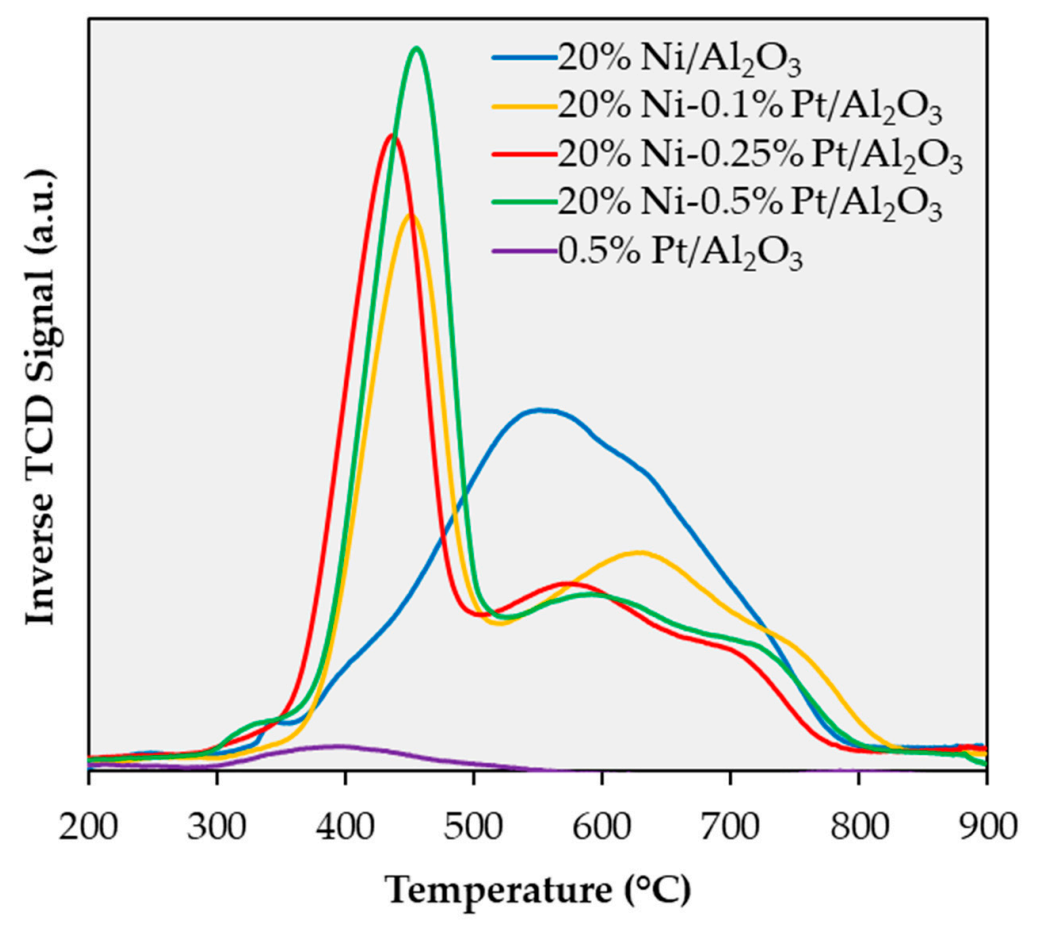

Figure 3. Temperature programmed reduction profiles of the catalysts studied.

The most notable difference between $20 \% \mathrm{Ni} / \mathrm{Al}_{2} \mathrm{O}_{3}$ and the Pt-containing catalysts is the prominent reduction maximum occurring between $440-460{ }^{\circ} \mathrm{C}$ displayed by all bimetallic formulations. The TPR profile of the $0.5 \% \mathrm{Pt} / \mathrm{Al}_{2} \mathrm{O}_{3}$ catalyst contains a single reduction event at a similar temperature, which suggests that the peaks centered at $\sim 450{ }^{\circ} \mathrm{C}$ are associated with the reduction of surface Pt. However, the $440-460{ }^{\circ} \mathrm{C}$ reduction maxima of the bimetallic catalysts are significantly larger than the maximum observed for the Pt-only catalyst. This indicates that the majority of the hydrogen uptake shown by the bimetallic catalysts between 350 and $500{ }^{\circ} \mathrm{C}$ must be due to the reduction of $\mathrm{NiO}$, with the fact that small additions of $\mathrm{Pt}$ to $\mathrm{Ni}$ catalysts can greatly enhance the reducibility of the latter being well-documented in the literature [49,52]. Pt is known to facilitate hydrogen spillover [46], resulting in the observed shift in the reduction temperature of oxidized Ni species. Indeed, while hydrogen spillover causes the reduction of oxidized $\mathrm{Ni}$ sites in close proximity to $\mathrm{Pt}$ to shift to lower temperatures, the same phenomenon may shift the reduction of other $\mathrm{Ni}^{2+}$ sites (e.g., $\mathrm{NiAl}_{2} \mathrm{O}_{4}$ ) to higher temperatures due to the preferential engagement of hydrogen in the reduction of the former type of Ni sites.

The TPR results discussed above are consistent with the results of $\mathrm{x}$-ray photoelectron spectroscopy (XPS) measurements performed on two representative catalysts, namely, $20 \% \mathrm{Ni} / \mathrm{Al}_{2} \mathrm{O}_{3}$ and $20 \%$ $\mathrm{Ni}-0.5 \% \mathrm{Pt} / \mathrm{Al}_{2} \mathrm{O}_{3}$ after reduction under $\mathrm{H}_{2}$ at $400{ }^{\circ} \mathrm{C}$ (the $\mathrm{Ni} 2 \mathrm{p}$ region of the resulting spectra is shown in Figure $\mathrm{A} 3$ in Appendix $\mathrm{A}$ ). Integration of the peak corresponding to $\mathrm{Ni}^{0}$ indicated that while the concentration of metallic $\mathrm{Ni}$ on the surface of $20 \% \mathrm{Ni} / \mathrm{Al}_{2} \mathrm{O}_{3}$ is $\sim 4.8$ at. $\%$, the corresponding value for $20 \% \mathrm{Ni}-0.5 \% \mathrm{Pt} / \mathrm{Al}_{2} \mathrm{O}_{3}$ is $\sim 7.0$ at. $\%$. This confirms that the addition of $\mathrm{Pt}$ to the $\mathrm{Ni}$ catalyst enhances its reducibility and leads to a considerably higher amount of reduced Ni sites at the catalyst surface.

$\mathrm{H}_{2}$ chemisorption was performed on the catalysts used in this study to identify the number of active sites available after the reduction step, i.e., preceding deoxygenation experiments (see Section 3.3). The amount of active metal sites was estimated assuming dissociative adsorption of the 
full amount of $\mathrm{H}_{2}$ adsorbed, which is displayed in Table 2 along with the theoretical $\mathrm{H}_{2}$ adsorption calculated for different scenarios. Notably, $\mathrm{H}_{2}$ adsorption increases dramatically from $0.095 \mathrm{~mL} / \mathrm{g}$ for $20 \% \mathrm{Ni} / \mathrm{Al}_{2} \mathrm{O}_{3}$ to $0.461 \mathrm{~mL} / \mathrm{g}$ for $20 \% \mathrm{Ni}-0.1 \% \mathrm{Pt} / \mathrm{Al}_{2} \mathrm{O}_{3}$. Assuming that the number of $\mathrm{Ni}$ metal surface sites remains unaffected by the addition of $\mathrm{Pt}$, the theoretical $\mathrm{H}_{2}$ adsorption expected after $0.1 \% \mathrm{Pt}$ addition (with an unlikely $100 \% \mathrm{Pt}$ metal dispersion) is calculated to be $0.152 \mathrm{~mL} / \mathrm{g}$. The fact that the observed increase in $\mathrm{H}_{2}$ adsorption is three times the theoretical value indicates that additional reduced Ni sites are created, which is in line with previous reports [49,52]. The amount of $\mathrm{H}_{2}$ adsorption does rise as $\mathrm{Pt}$ metal loading increases further; however, higher $\mathrm{Pt}$ metal loadings do not display the dramatic adsorption difference observed between the monometallic catalyst and $20 \% \mathrm{Ni}-0.1 \% \mathrm{Pt} / \mathrm{Al}_{2} \mathrm{O}_{3}$. In fact, the $\mathrm{H}_{2}$ adsorption trend roughly corresponds to the amount expected from the incorporation of additional $\mathrm{Pt}$ (as calculated for a scenario assuming 50\% $\mathrm{Pt}$ metal dispersion). Indeed, while $20 \% \mathrm{Ni}-0.25 \% \mathrm{Pt} / \mathrm{Al}_{2} \mathrm{O}_{3}$ and $20 \% \mathrm{Ni}-0.5 \% \mathrm{Pt} / \mathrm{Al}_{2} \mathrm{O}_{3}$ adsorb 0.560 and $0.639 \mathrm{~mL} / \mathrm{g}$ $\mathrm{H}_{2}$, respectively, their theoretical adsorption would be $0.461+(0.071-0.028)=0.504 \mathrm{~mL} / \mathrm{g}$ for $20 \%$ $\mathrm{Ni}-0.25 \% \mathrm{Pt} / \mathrm{Al}_{2} \mathrm{O}_{3}$ and $0.560+(0.144-0.071)=0.633 \mathrm{~mL} / \mathrm{g}$ for $20 \% \mathrm{Ni}-0.5 \% \mathrm{Pt} / \mathrm{Al}_{2} \mathrm{O}_{3}$ if the number of Ni metal surface sites remained unaffected by these increases in Pt loading. Therefore, albeit the addition of $0.1 \% \mathrm{Pt}$ increases the number of adsorption sites from $2.55 \times 10^{18} / \mathrm{g}$ to $1.24 \times 10^{19} / \mathrm{g}$, further augmenting the $\mathrm{Pt}$ loading from $0.1 \%$ to $0.5 \%$ affords significantly lower increases in the amount of reduced Ni surface sites, with $20 \% \mathrm{Ni}-0.5 \% \mathrm{Pt} / \mathrm{Al}_{2} \mathrm{O}_{3}$ displaying $1.72 \times 10^{19} / \mathrm{g}$ adsorption sites.

Table 2. Pulsed $\mathrm{H}_{2}$ chemisorption results of the catalysts studied.

\begin{tabular}{|c|c|c|c|c|}
\hline Catalyst & $\begin{array}{c}\mathrm{H}_{2} \text { Ads. } \\
(\mathrm{mL} / \mathrm{g})\end{array}$ & $\begin{array}{c}\mathrm{H}_{2} \text { Ads. on Pt for } \\
50 \% \text { Pt Dispersion } \\
(\mathrm{mL} / \mathrm{g})^{1}\end{array}$ & $\begin{array}{c}\mathrm{H}_{2} \text { Ads. on Pt for } \\
100 \% \text { Pt Dispersion } \\
(\mathrm{mL} / \mathrm{g})^{1}\end{array}$ & $\begin{array}{c}\mathrm{H}_{2} \text { Ads. on Ni-Pt for } \\
100 \% \text { Pt Dispersion } \\
(\mathrm{mL} / \mathrm{g})^{2}\end{array}$ \\
\hline $20 \% \mathrm{Ni} / \mathrm{Al}_{2} \mathrm{O}_{3}$ & 0.095 & - & - & - \\
\hline $20 \% \mathrm{Ni}-0.1 \% \mathrm{Pt} / \mathrm{Al}_{2} \mathrm{O}_{3}$ & 0.461 & 0.028 & 0.057 & 0.152 \\
\hline $20 \% \mathrm{Ni}-0.25 \% \mathrm{Pt} / \mathrm{Al}_{2} \mathrm{O}_{3}$ & 0.560 & 0.071 & 0.144 & 0.239 \\
\hline $20 \% \mathrm{Ni}-0.5 \% \mathrm{Pt} / \mathrm{Al}_{2} \mathrm{O}_{3}$ & 0.639 & 0.144 & 0.287 & 0.382 \\
\hline $0.5 \% \mathrm{Pt} / \mathrm{Al}_{2} \mathrm{O}_{3}$ & 0.371 & 0.144 & 0.287 & 0.287 \\
\hline
\end{tabular}

${ }^{1}$ Values shown are calculated solely from the theoretical Pt metal dispersion. ${ }^{2}$ Values shown are theoretical $\mathrm{H}_{2}$ adsorptions if Ni metal sites were unaffected by the addition of Pt.

Since any $\mathrm{CO}$ evolved via decarbonylation risks interacting strongly with the surface of $\mathrm{Ni}$ catalysts, leading to their poisoning [6,7], the interaction of $\mathrm{CO}$ with these catalysts is of great interest. This is particularly true given that the addition of small amounts of Pt has been reported to lower the binding strength of $\mathrm{CO}$ on supported $\mathrm{Ni}$ catalysts and avoid the poisoning of active metal sites [49]. Therefore, two representative catalysts, namely, $20 \% \mathrm{Ni} / \mathrm{Al}_{2} \mathrm{O}_{3}$ and $20 \% \mathrm{Ni}-0.5 \% \mathrm{Pt} / \mathrm{Al}_{2} \mathrm{O}_{3}$, were studied by means of CO temperature programmed desorption (TPD). The resulting TPD profiles (shown in Figure 4) include traces corresponding to $\mathrm{CO}$ and $\mathrm{CO}_{2}$, as both gases are evolved in these experiments through a complex desorption mechanism in which $\mathrm{CO}$ can be converted to $\mathrm{CO}_{2}$ via the Boudouard and water gas shift (WGS) reactions [49], with the latter reaction occurring due to the dehydroxylation of alumina [53]. Irrespective of the desorbed molecule, all desorption events take place in a temperature regime $\left(<200{ }^{\circ} \mathrm{C}\right)$ characteristic of single site chemisorption, which is in turn indicative of high coverage [49]. Comparing the traces in Figure 4 corresponding to $20 \%$ $\mathrm{Ni} / \mathrm{Al}_{2} \mathrm{O}_{3}$ and $20 \% \mathrm{Ni}-0.5 \% \mathrm{Pt} / \mathrm{Al}_{2} \mathrm{O}_{3}$, it is evident that the peak temperature for $\mathrm{CO}$ desorption from the Pt-promoted catalyst is shifted to slightly lower temperature relative to the Ni-only catalyst. This confirms that $\mathrm{Pt}$ addition does lower the $\mathrm{CO}$ binding energy, which is advantageous since curbing the adsorption of $\mathrm{CO}$ on the metal should reduce the blocking of sites for deoxygenation reactions and help to prevent catalyst coking. Interestingly, above $100{ }^{\circ} \mathrm{C}$, the Pt-promoted catalysts desorb a higher amount of $\mathrm{CO}_{2}$ than the Ni-only formulation, which can be attributed to an enhancement of the WGS reaction since thermogravimetric analysis results (vide infra) suggest that $\mathrm{Pt}$ addition disfavors the Boudouard reaction. In turn, this is consistent with previous reports in which a lowering of the 
binding energy of $\mathrm{CO}$ favors the WGS reaction and $\mathrm{CO}_{2} / \mathrm{H}_{2}$ formation [49]. This opens the prospect of in situ hydrogen generation that could reduce the need for exogenous hydrogen, which remains one of the main drawbacks to be overcome by deoxygenation technology.

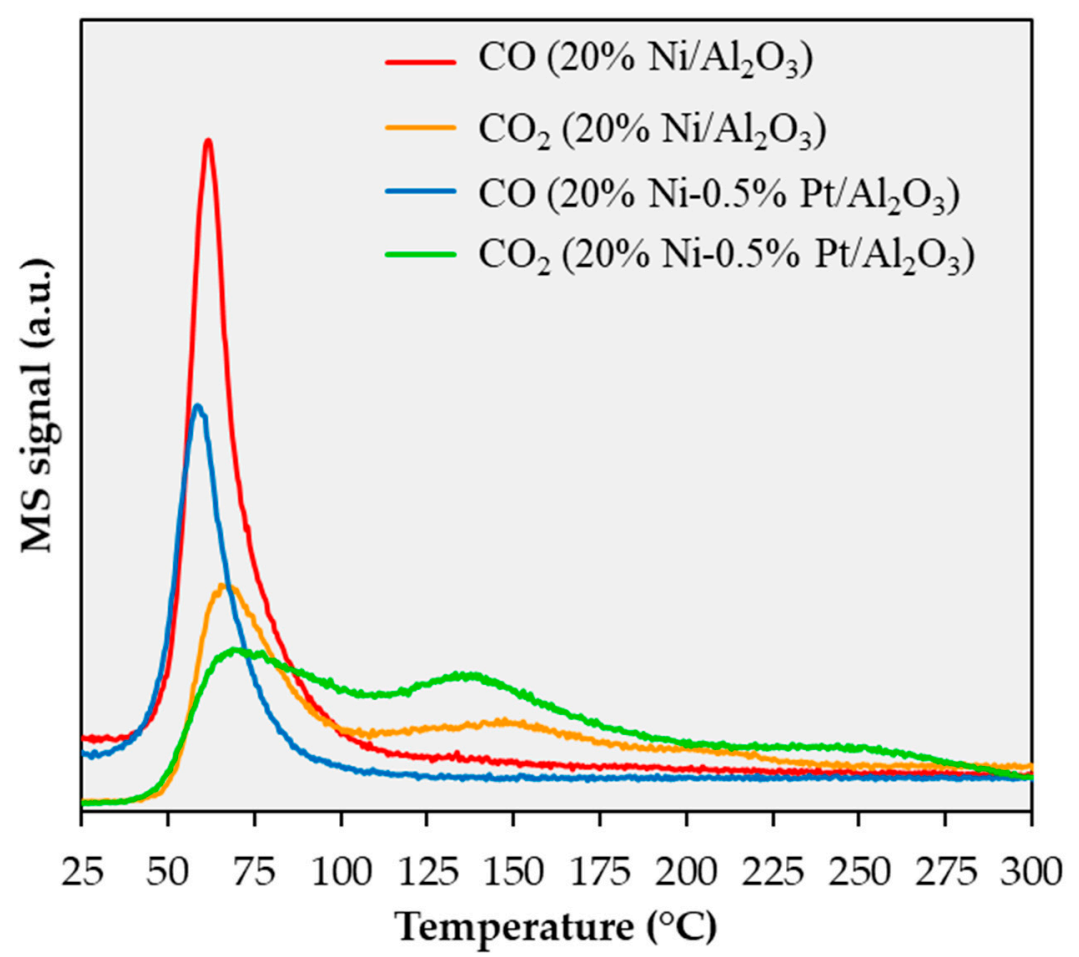

Figure 4. CO temperature programmed desorption profile of the catalysts studied. Catalysts were pre-reduced in situ at $350{ }^{\circ} \mathrm{C}$ for $3 \mathrm{~h}$.

Given the importance of the interaction between $\mathrm{CO}$ and the surface of the catalysts studied, $\mathrm{CO}$ TPD analyses were complemented by $\mathrm{CO}$ adsorption studies coupled with diffuse reflectance infrared Fourier transform spectroscopy (DRIFTS) measurements, the results of which are included in Figure 5.

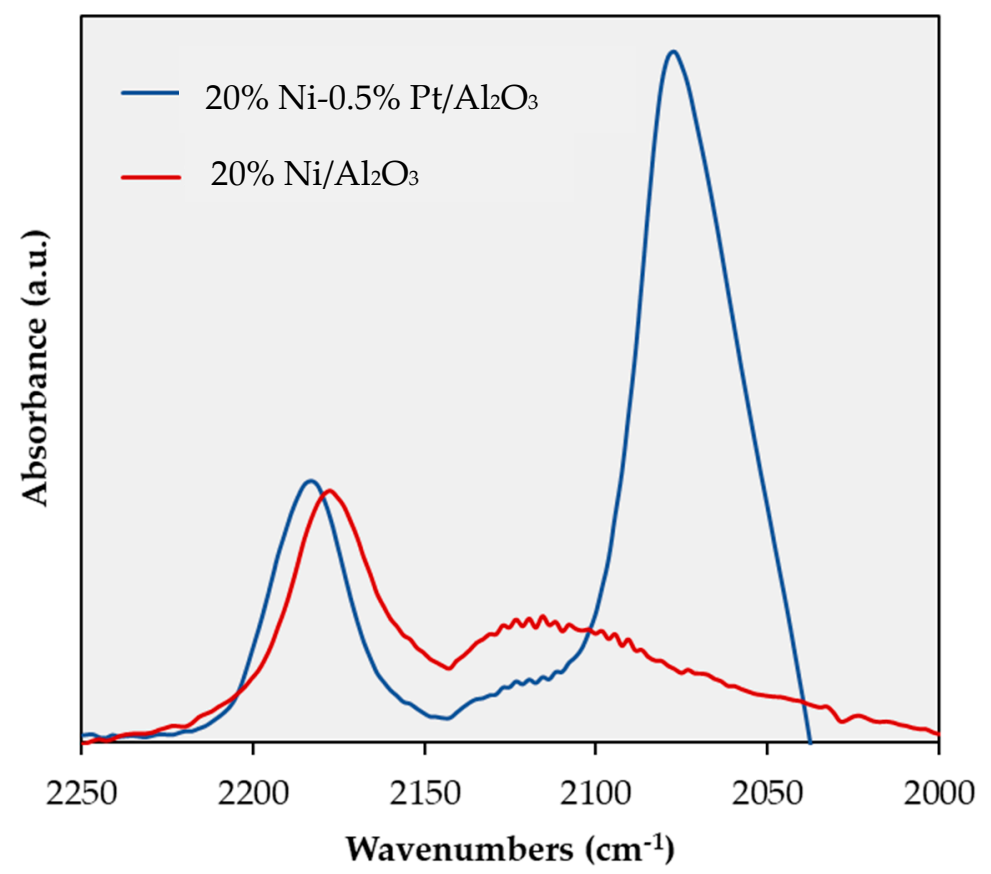

Figure 5. In situ DRIFTS spectra of $20 \% \mathrm{Ni} / \mathrm{Al}_{2} \mathrm{O}_{3}$ (a) and $20 \% \mathrm{Ni}-0.5 \% \mathrm{Pt} / \mathrm{Al}_{2} \mathrm{O}_{3}$ (b) after CO adsorption. 
As seen in Figure 5, two bands are observed on both catalysts-namely, a well-defined peak at $\sim 2180 \mathrm{~cm}^{-1}$ and a broad feature at $\sim 2120 \mathrm{~cm}^{-1}$-both of which can be assigned to CO adsorbed on metallic nickel sites $[54,55]$. Note that differences in the frequency of these bands in this and previously published reports can be attributed to the different pretreatments employed. In addition, the Pt-promoted catalyst also shows a large and well-defined peak at $2077 \mathrm{~cm}^{-1}$, which is assigned to $\mathrm{CO}$ adsorbed on Pt sites [56]. However, of primary interest is the shift observed in the CO stretching frequency of the peak assigned to $\mathrm{CO}$ adsorbed on metallic Ni sites, the maximum of which occurs at 2175 and at $2183 \mathrm{~cm}^{-1}$ for the Ni-only and Ni-Pt catalysts, respectively. This shift is similar to that observed for other metal alloys and indicates that the alloying of $\mathrm{Ni}$ and $\mathrm{Pt}$ reduces electron back-donation from the Ni metal, which in turn results in a weaker Ni-CO bond [54,57]. Notably, this is in agreement with the conclusion that Pt addition lowers the binding strength of $\mathrm{CO}$ on supported $\mathrm{Ni}$ catalysts based on the CO TPD results reported above and elsewhere [49]. Upon heating at $50{ }^{\circ} \mathrm{C}$ in inert atmosphere, the IR absorption bands above $2100 \mathrm{~cm}^{-1}$ (i.e., those associated with $\mathrm{CO}$ adsorbed on Ni sites) disappeared (results not shown). This is consistent with previously published results [55] and confirms the low thermal stability and labile nature of these adspecies, which Parizotto et al. have claimed is indicative of changes in the superficial structure of $\mathrm{Ni}$ caused by the presence of small amounts of Pt [55].

\subsection{Tristearin Deoxygenation in Semi-batch Mode}

The results of tristearin deoxygenation experiments are summarized in Table 3.

Table 3. Semi-batch deoxygenation of tristearin (580 psi of $\mathrm{H}_{2}, 260{ }^{\circ} \mathrm{C}, 3 \mathrm{~h}$ reaction time) ${ }^{1}$.

\begin{tabular}{|c|c|c|c|c|}
\hline Catalyst & $\begin{array}{c}\text { Conversion } \\
(\%)^{2}\end{array}$ & $\begin{array}{l}\text { Selectively to (Yield } \\
\text { of) C10-C17 (\%) }\end{array}$ & $\begin{array}{l}\text { Selectively to (Yield } \\
\text { of) C17 (\%) }\end{array}$ & $\begin{array}{l}\text { Selectively to (Yield } \\
\text { of) C18 (\%) } 5,6\end{array}$ \\
\hline $20 \% \mathrm{Ni} / \mathrm{Al}_{2} \mathrm{O}_{3}$ & 2 & $83(2)$ & $83(2)$ & $3(<1)$ \\
\hline $20 \% \mathrm{Ni}-0.1 \% \mathrm{Pt} / \mathrm{Al}_{2} \mathrm{O}_{3}$ & 32 & $96(23)$ & $72(15)$ & $0(0)$ \\
\hline $20 \% \mathrm{Ni}-0.25 \% \mathrm{Pt} / \mathrm{Al}_{2} \mathrm{O}_{3}$ & 66 & $99(65)$ & $72(48)$ & $0(0)$ \\
\hline $20 \% \mathrm{Ni}-0.5 \% \mathrm{Pt} / \mathrm{Al}_{2} \mathrm{O}_{3}$ & 100 & $96(96)$ & $65(65)$ & $2(2)$ \\
\hline $0.5 \% \mathrm{Pt} / \mathrm{Al}_{2} \mathrm{O}_{3}$ & 5 & $70(4)$ & $65(3)$ & $3(<1)$ \\
\hline
\end{tabular}

${ }^{1}$ All experiments for which results are shown were performed a minimum of two times and the values presented are the average of multiple experiments, with the average of the standard deviations obtained for all catalysts being $4.6,1.8$, and $2.8 \%$ for conversion, selectivity to $\mathrm{C} 10-\mathrm{C} 17$, and selectivity to $\mathrm{C} 17$, respectively. ${ }^{2}$ Conversion $=\mathrm{wt} . \%$ of product with $\mathrm{bp}<375{ }^{\circ} \mathrm{C} .{ }^{3}$ Selectivity to $\mathrm{C} 10-\mathrm{C} 17=100 \times\left[\left(\right.\right.$ wt. $\%$ of product with $\mathrm{bp}<314{ }^{\circ} \mathrm{C}-$ wt. $\%$ of product with $\left.\mathrm{bp}<177^{\circ} \mathrm{C}\right) /\left(\right.$ wt. $\%$ of product with $\left.\left.\mathrm{bp}<375^{\circ} \mathrm{C}\right)\right] .{ }^{4}$ Selectivity to $\mathrm{C} 17=100 \times[$ (wt. $\%$ of product with bp $<314^{\circ} \mathrm{C}-$ wt. $\%$ of product with $\left.\mathrm{bp}<295^{\circ} \mathrm{C}\right) /\left(\right.$ wt. $\%$ of product with $\left.\left.\mathrm{bp}<375^{\circ} \mathrm{C}\right)\right] .{ }^{5}$ Selectivity to $\mathrm{C} 18=100 \times$ [(wt. $\%$ of product with $\mathrm{bp}<325^{\circ} \mathrm{C}-$ wt. $\%$ of product with $\left.\mathrm{bp}<314{ }^{\circ} \mathrm{C}\right) /\left(\right.$ wt. $\%$ of product with $\left.\mathrm{bp}<375{ }^{\circ} \mathrm{C}\right)$ ]. ${ }^{6}$ The corresponding yield (conversion $\times$ selectivity) values are shown between parentheses.

Remarkably, whereas the monometallic catalyst afforded a negligible (2\%) conversion, the $20 \%$ $\mathrm{Ni}-0.5 \% \mathrm{Pt} / \mathrm{Al}_{2} \mathrm{O}_{3}$ catalyst exhibited a quantitative conversion of the feed to diesel-like hydrocarbons, and the gas chromatograms and boiling point distribution plots (BPDPs) are shown in Figure 6.

Since monometallic Pt-based catalysts have been widely reported to be active in the deoxygenation of lipids to fuel-like hydrocarbons $[19,22,25,30,58]$, a Pt-only catalyst with the same loading as that used for the best $\mathrm{Ni}$-Pt formulation identified in this study ( $0.5 \mathrm{wt} . \%)$ was tested using the same reaction conditions. Although $0.5 \% \mathrm{Pt} / \mathrm{Al}_{2} \mathrm{O}_{3}$ did indeed show a higher conversion (5\%) than $20 \% \mathrm{Ni} / \mathrm{Al}_{2} \mathrm{O}_{3}$ $(2 \%)$, all bimetallic formulations achieved a considerably greater tristearin conversion. Tellingly, the bimetallic catalyst with the lowest Pt loading displayed a conversion of $21 \%$, with this value being higher than the sum of the conversions achieved by the monometallic catalysts. This indicates that its improved performance stems from a synergistic effect between $\mathrm{Ni}$ and $\mathrm{Pt}$ and not from the addition of their individual contributions. Indeed, $20 \% \mathrm{Ni}-0.5 \% \mathrm{Pt} / \mathrm{Al}_{2} \mathrm{O}_{3}$ was found to afford a quantitative conversion and a $96 \%$ yield of diesel range (C10-C17) hydrocarbons with a $65 \%$ selectivity to $\mathrm{C} 17$. The identity of individual products was confirmed via MS, which verified that complete deoxygenation was achieved since fuel-like hydrocarbons were the only products detected. The dramatic increase 
in tristearin conversion observed as Pt loading increases from $0.1-0.5 \%$ is curious, particularly since pulsed $\mathrm{H}_{2}$ chemisorption revealed that increasing the Pt loading beyond $0.1 \%$ did not significantly augment the amount of reduced Ni sites (see Section 2.1). Therefore, other phenomena must be invoked to explain the increased conversion. As mentioned above, $\mathrm{Pt}$ addition curbs the adsorption of $\mathrm{CO}$ (see Section 2.1) - and thus coke formation (see Section 2.3)—on surface Ni active sites, resulting in a higher amount of active sites available for deoxygenation reactions, which can in turn explain how promotion with Pt can lead to improved conversion.

a)

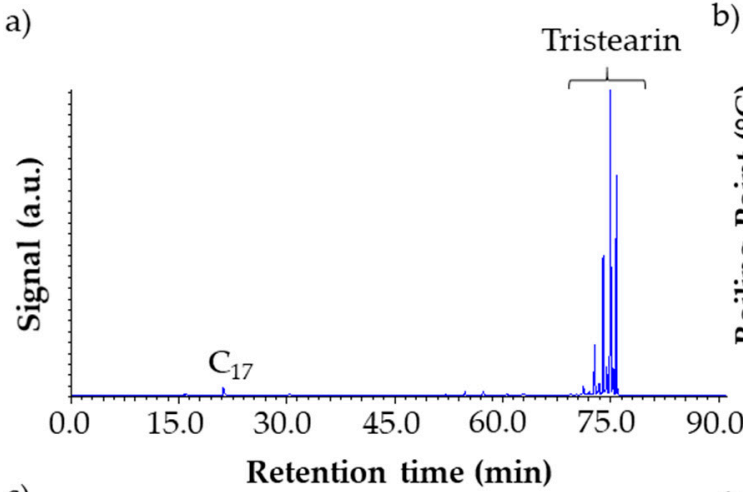

c)

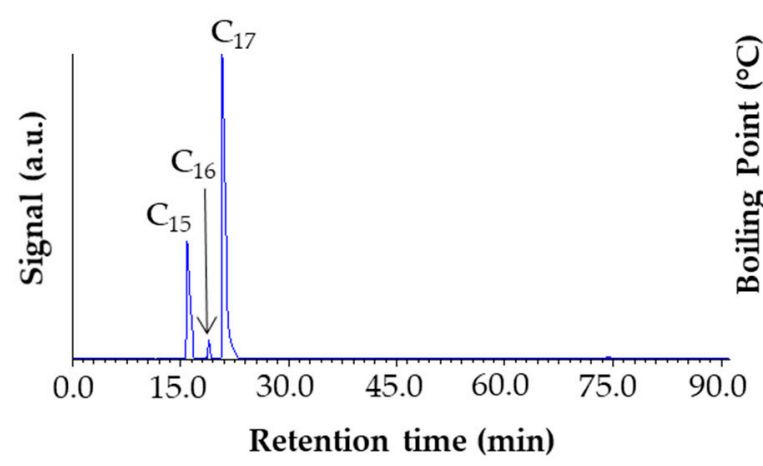

b)

d)
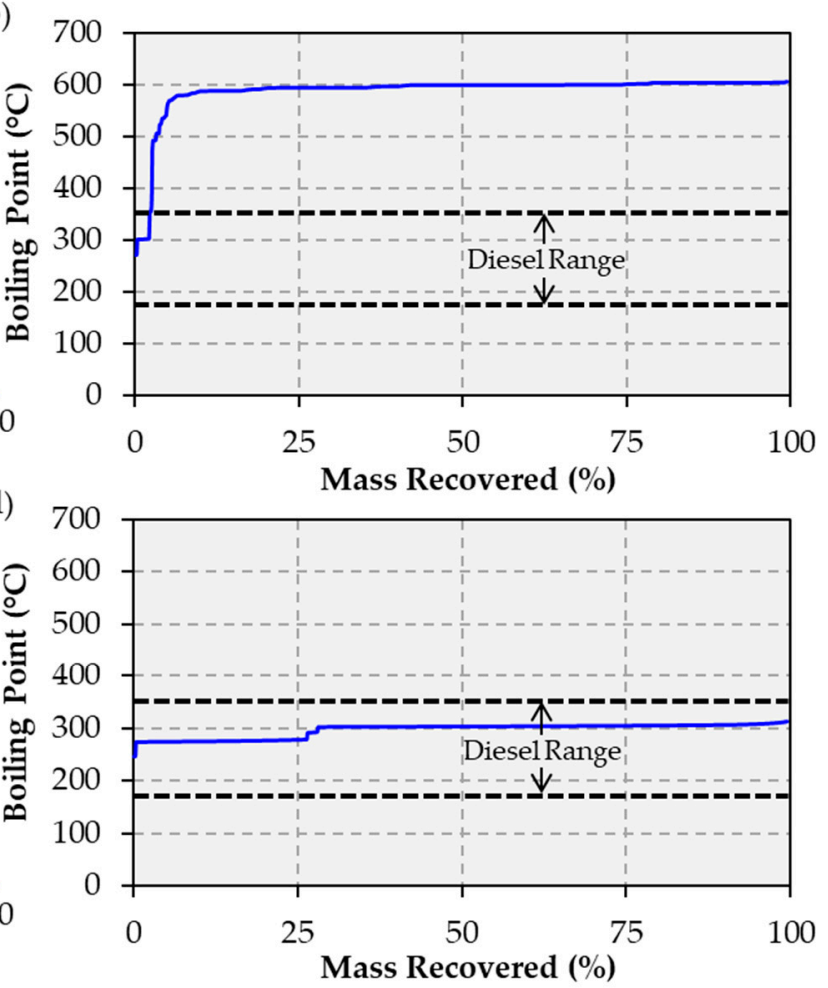

Figure 6. Gas chromatograms and BPDPs of the liquid products collected from the deoxygenation of tristearin with $20 \% \mathrm{Ni} / \mathrm{Al}_{2} \mathrm{O}_{3}(\mathbf{a}, \mathbf{b})$ and $20 \% \mathrm{Ni}-0.5 \% \mathrm{Pt} / \mathrm{Al}_{2} \mathrm{O}_{3}(\mathbf{c}, \mathbf{d})$.

It is important to note that all deoxygenation reactions were performed using a $100 \% \mathrm{H}_{2}$ atmosphere, which has been shown to lead to improved results, even if $\mathrm{H}_{2}$ is not directly consumed by the deCO reactions $[5,31,33,59]$. The deoxygenation of lipids typically proceeds preferentially via HDO at lower reaction temperatures when both $\mathrm{HDO}$ and $\mathrm{deCO}_{\mathrm{x}}$ pathways are viable [60-62]. Therefore, it is remarkable that all catalysts yielded negligible amounts $(\leq 1 \%)$ of $\mathrm{C} 18$ - the primary HDO product-indicating that deoxygenation proceeds almost exclusively via deCO $\mathrm{CO}_{\mathrm{x}}$ Parenthetically, most experiments also yielded small amounts $(<1 \%)$ of stearyl stearate, an intermediate formed in the deoxygenation of lipids through esterification reactions involving fatty acid and alcohol intermediates [36]. Indeed, for some experiments involving Ni-Pt catalysts, the MS analysis of the product mixture (not shown) revealed small amounts of stearic acid, albeit neither fatty acids nor alcohols were detected in repeat experiments. Nevertheless, the stearic acid observed in some product mixtures suggests that the conversion of tristearin to hydrocarbons proceeds through a fatty acid intermediate, which is in line with previous reports [31,35] and explains the stearyl stearate detected $[32,36]$. Notably, the small amounts of intermediates observed suggest that deoxygenation occurs rapidly after intermediate formation, indicating that the latter represents the rate limiting step. 


\subsection{Spent Catalyst Characterization and Catalyst Stability}

While coking represents the primary deactivation pathway of Ni catalysts, it has been suggested that the addition of $\mathrm{Pt}$ to Ni-based formulations can lessen deactivation by curbing coke formation [49]. Therefore, representative spent catalysts were subjected to thermogravimetric analysis (TGA) in air, with the resulting profiles being shown in Figure 7.

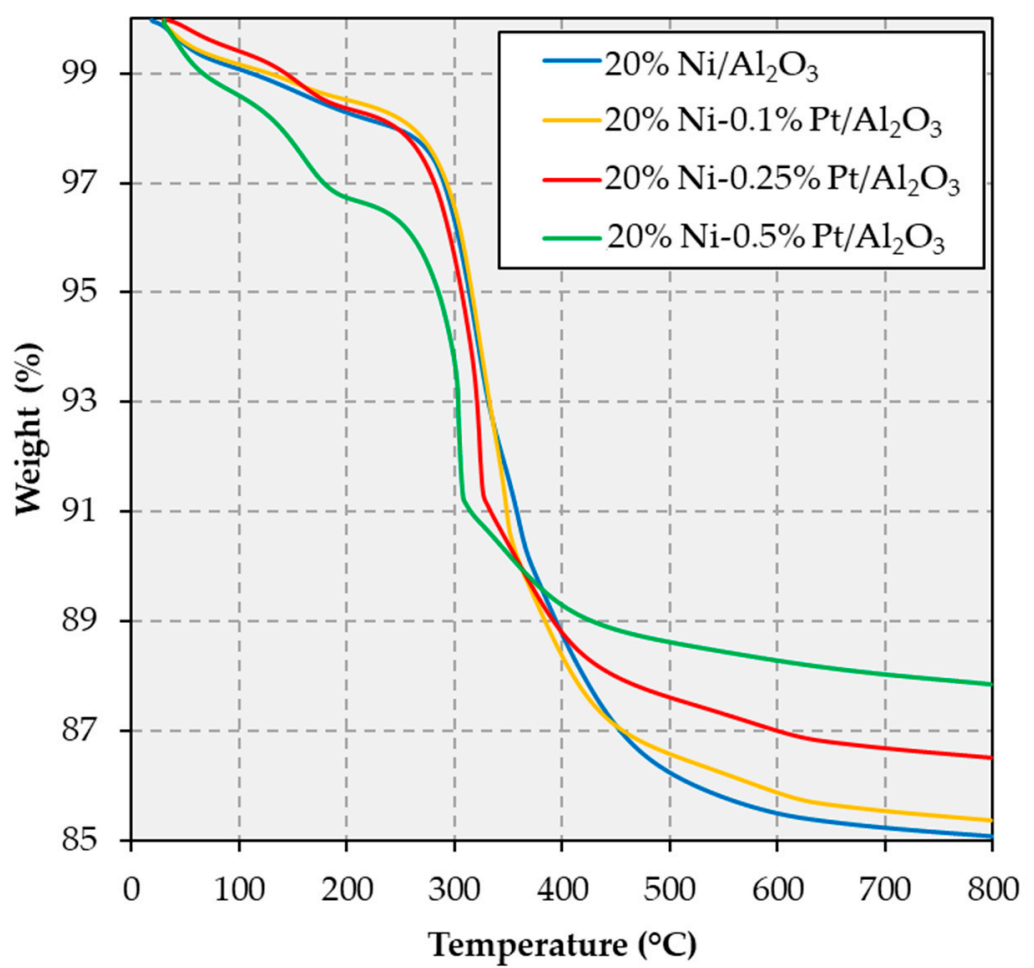

Figure 7. Thermogravimetric analysis of the spent catalysts recovered from deoxygenation experiments.

All TGA profiles show their major weight loss event below $400{ }^{\circ} \mathrm{C}$, which is attributed to the desorption and / or combustion of residual reactants, intermediates, and products (or soft coke) [63]. Moreover, weight losses are relatively minor above $400{ }^{\circ} \mathrm{C}$, indicating that minimal amounts of graphitic or hard coke are present [63]. Saliently, there is a clear inverse relationship between total weight loss and Pt metal loading. Indeed, the total weight loss is $14.9,14.6,13.5$, and $12.2 \%$, for $20 \%$ $\mathrm{Ni} / \mathrm{Al}_{2} \mathrm{O}_{3}, 20 \% \mathrm{Ni}-0.1 \% \mathrm{Pt} / \mathrm{Al}_{2} \mathrm{O}_{3}, 20 \% \mathrm{Ni}-0.25 \% \mathrm{Pt} / \mathrm{Al}_{2} \mathrm{O}_{3}$, and $20 \% \mathrm{Ni}-0.5 \% \mathrm{Pt} / \mathrm{Al}_{2} \mathrm{O}_{3}$, respectively. Similarly, there is also an inverse relationship between the extent of coking/fouling and catalytic activity, $20 \% \mathrm{Ni} / \mathrm{Al}_{2} \mathrm{O}_{3}$, and $20 \% \mathrm{Ni}-0.5 \% \mathrm{Pt} / \mathrm{Al}_{2} \mathrm{O}_{3}$ affording negligible and quantitative conversion, respectively. Therefore, the improved activity obtained by increasing Pt loading may be attributed, at least in part, to reduced coking and fouling. This can be attributed to the ability of Pt to facilitate the spillover of atomic $\mathrm{H}$ onto the catalyst surface [49], thereby facilitating the desorption of unsaturated adspecies via hydrogenation, and hence the removal of coke precursors and material blocking pores and active sites [64]. However, given that the weight loss difference between the worst and best performing catalyst is only $2.7 \%$, reduced coking and fouling does not appear to be the major promoting effect from $\mathrm{Pt}$ addition influencing catalyst performance, although it does appear to be a minor contributing factor.

In order to test the chemical stability of the catalysts, representative product mixtures were filtered to remove the spent solid catalysts before analyzing the filtrates via inductively-coupled plasma-atomic emission spectroscopy (ICP-AES) to test for $\mathrm{Ni}$ and $\mathrm{Pt}$ in solution. These leaching studies revealed $<0.1 \mathrm{ppm}$ of $\mathrm{Ni}$ and $<0.5 \mathrm{ppm}$ of $\mathrm{Pt}$ in the filtrates recovered from the reaction involving $20 \% \mathrm{Ni}-0.5 \%$ $\mathrm{Pt} / \mathrm{Al}_{2} \mathrm{O}_{3}$, which provides a first indication of the stability of this catalyst under the reaction conditions 
employed. Parenthetically, this is in agreement with the results of previous studies in which supported $\mathrm{Ni}$ catalysts (including $20 \% \mathrm{Ni} / \mathrm{Al}_{2} \mathrm{O}_{3}$ ) displayed similar chemical stability when tested under more stringent reaction conditions ( $\geq 350^{\circ} \mathrm{C}, 4-6 \mathrm{~h}$ reaction time) [31,35]. In addition, in order to investigate the possibility of metal particle aggregation and/or transition metal redistribution, representative spent catalysts - namely, $20 \% \mathrm{Ni} / \mathrm{Al}_{2} \mathrm{O}_{3}$ and $20 \% \mathrm{Ni}-0.5 \% \mathrm{Pt} / \mathrm{Al}_{2} \mathrm{O}_{3}$ - were analyzed via TEM-EDS (see Figures 8 and $\mathrm{A} 4$ in Appendix A).

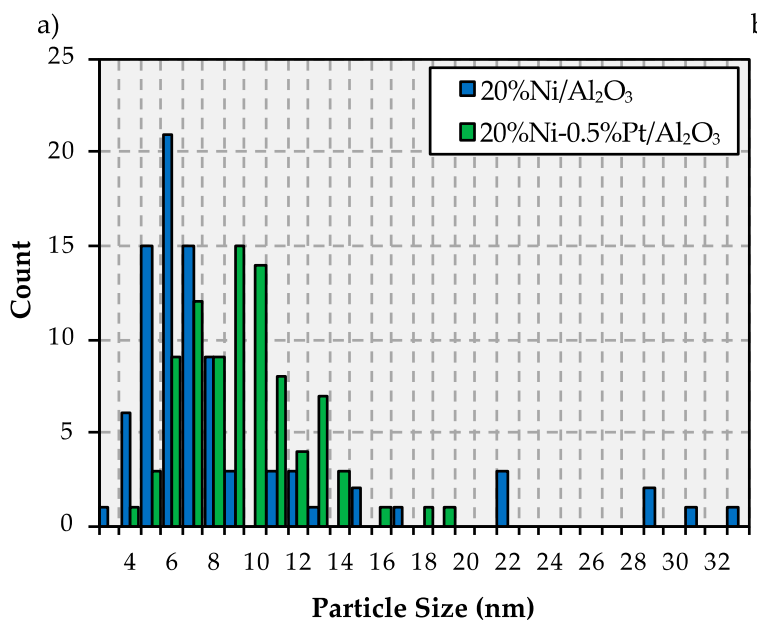

b)

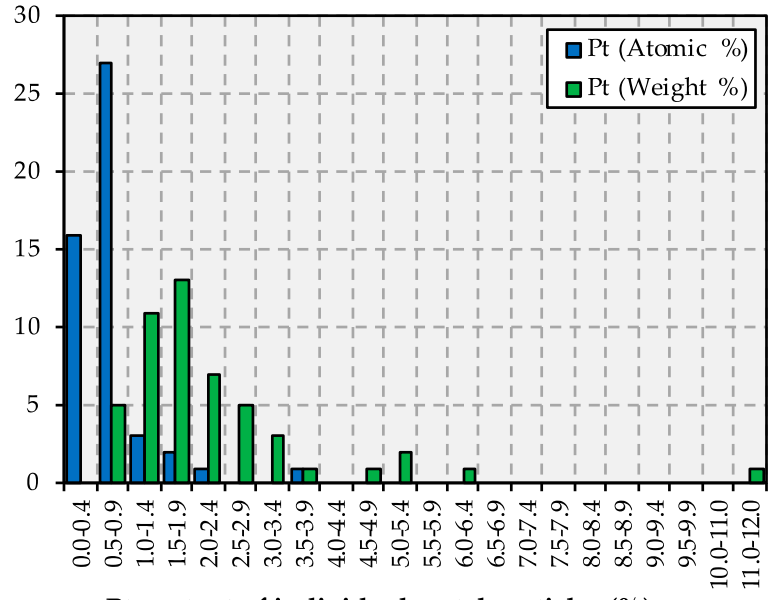

Pt content of individual metal particles (\%)

Figure 8. Particle size histograms for the spent $20 \% \mathrm{Ni}-/ \mathrm{Al}_{2} \mathrm{O}_{3}$ and $20 \% \mathrm{Ni}-0.5 \% \mathrm{Pt} / \mathrm{Al}_{2} \mathrm{O}_{3}$ catalysts (a) and metallic composition histograms for the spent $20 \% \mathrm{Ni}-0.5 \% \mathrm{Pt} / \mathrm{Al}_{2} \mathrm{O}_{3}$ formulation (b).

Albeit the vast majority of metal particles within both spent catalysts remained within the same narrow size range observed for the fresh formulations, i.e., between 5 and $13 \mathrm{~nm}$ (see Figure 2a), a relatively small amount of larger particles were formed during the reaction, this effect being slightly more pronounced for the Ni-only catalyst. Nevertheless, as shown in Figure 8a, the vast majority of metal particles in the spent monometallic formulation range between 5 and $8 \mathrm{~nm}$, whereas the majority of metal particles in the spent bimetallic catalyst range between 6 and $13 \mathrm{~nm}$, with these results being similar to those observed for the fresh formulations (see Figure 2a). The particle composition histogram of the spent $20 \% \mathrm{Ni}-0.5 \% \mathrm{Pt} / \mathrm{Al}_{2} \mathrm{O}_{3}$ catalyst (Figure $8 \mathrm{~b}$ ) shows that the majority of metal particles display a Pt content between 0.5 and $3.4 \mathrm{wt} . \%$ and a slightly narrower $\mathrm{Pt}$ content distribution than that displayed by the fresh formulation (Figure $2 b$ ). As was also observed in the fresh bimetallic catalyst (see Figure A2 in Appendix A), the elemental maps for the spent Ni-Pt formulation (displayed in Figure A4 in Appendix A) show that Pt-rich regions coincide with the location of Ni particles. These results indicate that these catalysts only experience small changes in particle size and transition metal distribution during the reaction, which suggests that these formulations are stable under the reaction conditions employed in this study.

Admittedly, catalyst stability is better assessed in experiments performed using a more industrially relevant set of reaction conditions than those employed in this study. Indeed, in order to test the lifetime or stability of a catalyst, a continuous fixed-bed reactor should ideally be employed to upgrade a realistic and concentrated feed (as opposed to a model, dilute feed) in an experiment lasting multiple days-as reported in a recent publication [65] - in order to monitor how conversion changes with time on stream. Such an experiment was performed and $20 \% \mathrm{Ni}-0.5 \% \mathrm{Pt} / \mathrm{Al}_{2} \mathrm{O}_{3}$ afforded excellent results, upgrading a solution of $75 \mathrm{wt} . \%$ yellow grease (used cooking oil) in dodecane at $375{ }^{\circ} \mathrm{C}$, using $0.5 \mathrm{~g}$ of catalyst and $0.5 \mathrm{~g}$ of $\mathrm{SiC}$ as catalyst diluent and a feed solution flow rate of $0.75 \mathrm{~mL} / \mathrm{h}$ (equivalent to a WHSV of $1 \mathrm{~h}^{-1}$ ). The liquid products recovered after 24,48 , and 72 hours consisted of $100 \%$ diesel-like (C10-C20) hydrocarbons, which suggests excellent catalyst stability. However, a detailed presentation 
and discussion of these results lies beyond the scope of the current article and will be the focus of a future contribution.

\section{Materials and Methods}

\subsection{Catalyst Preparation}

Catalysts were prepared by excess wetness impregnation using $\mathrm{Ni}\left(\mathrm{NO}_{3}\right)_{2} \cdot 6 \mathrm{H}_{2} \mathrm{O}$ (Alfa Aesar, Haverhill, MA, USA) and/or Pt $\left(\mathrm{NH}_{3}\right)_{4}\left(\mathrm{NO}_{3}\right)_{2}$ (Sigma Aldrich, St. Louis, MO, USA) as the metal precursors. Beads of $\gamma-\mathrm{Al}_{2} \mathrm{O}_{3}$ (Sasol, Johannesburg, South Africa; surface area of $216 \mathrm{~m}^{2} / \mathrm{g}$ ) used as the support were crushed to a particle size of $<150 \mu \mathrm{m}$ before impregnation. Each Ni-based catalyst contained $20 \mathrm{wt} . \% \mathrm{Ni}$, while Pt loading was varied at 0.0, 0.1, 0.25, and $0.5 \mathrm{wt} . \%$. A monometallic $0.5 \mathrm{wt} . \% \mathrm{Pt} / \mathrm{Al}_{2} \mathrm{O}_{3}$ catalyst was also prepared for comparison purposes. After each impregnation, materials were dried overnight at $60^{\circ} \mathrm{C}$ under vacuum prior to calcination for $3 \mathrm{~h}$ at $500{ }^{\circ} \mathrm{C}$ in static air. $\mathrm{Ni}$-Pt catalysts were prepared using two sequential impregnation steps.

\subsection{Catalyst Characterization}

The surface area, pore volume, and average pore radius of the catalysts were determined by $\mathrm{N}_{2}$ physisorption using previously described instruments and methods [30]. The average $\mathrm{NiO}$ particle size was calculated by applying the Scherrer equation to the $\mathrm{NiO}$ peaks observed in powder X-ray diffractograms. The equipment and procedures for acquiring the $\mathrm{X}$-ray diffractograms are described elsewhere [35]. TEM observations were conducted on the $20 \% \mathrm{Ni} / \mathrm{Al}_{2} \mathrm{O}_{3}$ and the $20 \% \mathrm{Ni}-0.5 \%$ $\mathrm{Pt} / \mathrm{Al}_{2} \mathrm{O}_{3}$ catalysts. The catalyst samples were loaded onto lacey carbon 400 mesh copper $(\mathrm{C} / \mathrm{Cu})$ grids through a sonication-assisted method in which a few milligrams of each catalyst were sonicated in $1 \mathrm{~mL}$ of ethanol for $20 \mathrm{~min}$ before placing one drop of the resulting suspension onto a blank $\mathrm{C} / \mathrm{Cu}$ grid that was subsequently allowed to dry in air. Samples thus prepared were then introduced into a Thermo Scientific (Waltham, MA, USA) Talos F200X analytical electron microscope, operated at $200 \mathrm{keV}$ and equipped with a 4 silicon drift detector (SDD)-based EDS system for quantitative chemical composition analysis and elemental distribution mapping. TPR and pulsed $\mathrm{H}_{2}$ chemisorption measurements were performed using calcined catalyst samples $(150 \mathrm{mg})$. The catalyst was loaded in a quartz U-tube reactor connected to a Micromeritics (Norcross, GA, USA) Autochem II analyzer equipped with a thermal conductivity detector (TCD). The temperature was monitored using a thermocouple situated in the catalyst bed. TPR measurements were performed using a method previously described [35]. Prior to pulsed $\mathrm{H}_{2}$ chemisorption measurements, calcined catalysts were reduced in situ under flowing $10 \% \mathrm{H}_{2} / \mathrm{Ar}$ at $350{ }^{\circ} \mathrm{C}$ for $1 \mathrm{~h}$. The reactor was then purged with $\mathrm{Ar}\left(50 \mathrm{~cm}^{3} / \mathrm{min}\right)$ at $450{ }^{\circ} \mathrm{C}$ for $30 \mathrm{~min}$ and subsequently cooled to $50^{\circ} \mathrm{C}$ under flowing Ar. After the TCD signal stabilized, $0.025 \mathrm{~cm}^{3}$ (STP) of $10 \% \mathrm{H}_{2} / \mathrm{Ar}$ was pulsed into a flow of Ar carrier gas $\left(50 \mathrm{~cm}^{3} / \mathrm{min}\right)$ directed to the reactor. Pulsing of $10 \% \mathrm{H}_{2}$ / Ar continued at 3 min intervals until the area of the $\mathrm{H}_{2}$ peaks remained constant. Samples were reduced prior to XPS measurements in a Lenton tube furnace under flowing $90 \% \mathrm{H}_{2}$ in $\mathrm{He}(10 \mathrm{~mL} / \mathrm{min})$ using a heat ramp of $10{ }^{\circ} \mathrm{C} / \mathrm{min}$ to reach a temperature of $400{ }^{\circ} \mathrm{C}$, which was held for one hour. After reduction, the tube furnace was filled with pure He, sealed using Swagelok ${ }^{\circledR}$ caps, transported to a Kratos (Manchester, UK) AXIS Supra XPS instrument, and placed inside a front-loading glovebox, which was then evacuated and subsequently filled with $\mathrm{N}_{2}$. The samples were removed from the sealed tube furnace, affixed to a sample bar using double-sided carbon tape, and loaded into the flexi-lock sample analysis chamber (SAC). Once the pressure reached below $10^{-7}$ torr, XPS analysis was performed using an Al mono-chromatic X-ray source $(1486.69 \mathrm{eV})$ and an electron flood gun for charge neutralization. Wide scans were performed at a pass energy of $160 \mathrm{eV}$ and high-resolution scans were performed at a pass energy of $20 \mathrm{eV}$. Data was analyzed using CasaXPS v. 2.3.19PR1.0 and all peaks were fitted using a Shirley background. Ni fits were developed using model parameters adapted from the work of Grovesnor et al. [66]. CO-TPD measurements were performed using a Micromeritics (Norcross, GA, USA) AutoChem II analyzer equipped with 
a mass spectrometer-Pfeiffer (Annecy, France) ThermoStar GSD301-programmed to follow the main mass-over-charge $(\mathrm{m} / \mathrm{z})$ signals attributed to $\mathrm{CO}$ and $\mathrm{CO}_{2}$-namely $\mathrm{m} / \mathrm{z}=28$ and $\mathrm{m} / \mathrm{z}=44$, respectively-with the contribution to the former signal stemming from $\mathrm{CO}_{2}$ being subtracted to fully deconvolute $\mathrm{CO}$ and $\mathrm{CO}_{2}$. Catalysts were pre-reduced in situ at $350{ }^{\circ} \mathrm{C}$ for $3 \mathrm{~h}$ under a flow of $10 \% \mathrm{H}_{2} / \mathrm{Ar}(60 \mathrm{~mL} / \mathrm{min})$. The catalysts were then purged at $450{ }^{\circ} \mathrm{C}$ for $30 \mathrm{~min}$ under flowing $\operatorname{Ar}(60 \mathrm{~mL} / \mathrm{min})$ prior to being cooled to room temperature and exposed to a flow $(100 \mathrm{~mL} / \mathrm{min})$ of ultrapure $\mathrm{CO}$ for $1 \mathrm{~h}$. The system was then flushed with $\operatorname{Ar}(100 \mathrm{~mL} / \mathrm{min})$ for $1 \mathrm{~h}$ to remove any trace of physisorbed $\mathrm{CO}$. TPD measurements were then performed by raising the temperature from room temperature to $800{ }^{\circ} \mathrm{C}$ at a rate of $10{ }^{\circ} \mathrm{C} / \mathrm{min}$. TGA of the spent catalysts was performed under flowing air $(50 \mathrm{~mL} / \mathrm{min})$ on a TA instruments Discovery Series thermogravimetric analyzer. The temperature was ramped from room temperature to $800{ }^{\circ} \mathrm{C}$ at a rate of $10^{\circ} \mathrm{C} / \mathrm{min}$. DRIFTS was performed on the catalysts after CO adsorption using a Thermo Scientific (Waltham, MA, USA) Nicolette 6700 FTIR instrument fitted with a Harrick Scientific (Pleasantville, NY, USA) praying mantis DRIFTS cell equipped with a high temperature reaction chamber. Both the catalyst pretreatment and the $\mathrm{CO}$ adsorption methods used prior to spectra acquisition mirrored those employed for the CO TPD measurements described above, except gases were flowed at a rate of $50 \mathrm{~mL} / \mathrm{min}$ due to limitations of the DRIFTS cell. For temperature-induced desorption studies coupled with DRIFTS measurements (results not shown), desorption was carried out in steps, pausing at each temperature at which spectra were acquired $\left(50,100,150,200\right.$, and $\left.250^{\circ} \mathrm{C}\right)$ for five minutes to allow for the temperature to stabilize and for a spectrum to be collected, and a ramp of $10^{\circ} \mathrm{C} / \mathrm{min}$ was used between these temperatures.

\subsection{Deoxygenation Experiments}

The calcined catalyst $\left(<150 \mu \mathrm{m}\right.$ particle size) was dried overnight at $60^{\circ} \mathrm{C}$ under vacuum before use. The dried catalyst $(0.5 \mathrm{~g})$ was then placed into a mechanically stirred $100 \mathrm{~mL}$ stainless steel autoclave (Parker, Cleveland, OH, USA), which was first purged with Ar and then pressurized to 70 psi with $10 \% \mathrm{H}_{2} / \mathrm{Ar}$ and a gas flow $(60 \mathrm{~mL} / \mathrm{min})$. This flow and pressure were maintained during a catalyst reduction step performed at $350{ }^{\circ} \mathrm{C}$ for $3 \mathrm{~h}$. Temperature was measured by a K-type thermocouple placed inside a thermowell. The reactor was then cooled to room temperature and purged with Ar. After cooling, the liquid solvent $(22 \mathrm{~g})$ was added through an opening on the reactor head. The reactor was then opened to add the solid feed (1.8 g). Dodecane (99+\%, from Alfa Aesar, Haverhill, MA, USA) and tristearin (95\%, from City Chemical, West Haven, CT, USA) were used as the solvent and the model triglyceride feed, respectively. The reactor was resealed and purged three times with $\mathrm{Ar}$ prior to being pressurized with $\mathrm{H}_{2}$ to 580 psi. Once at this pressure, the reactor was heated to $260{ }^{\circ} \mathrm{C}$ under a constant flow of $\mathrm{H}_{2}(60 \mathrm{~mL} / \mathrm{min})$, while the contents were mechanically stirred (1000 rpm). Stirring and $\mathrm{H}_{2}$ gas flow were held constant through the duration of the experiment $(3 \mathrm{~h})$. Volatile liquid products were collected in a condenser placed downstream of the reactor and upstream from a backpressure regulator. At the end of the experiment, the reactor was cooled to room temperature (using forced air and an ice bath), depressurized, and opened. The liquid and solid products recovered were separated by gravity filtration. The solids were rinsed with chloroform to recover additional liquid product from the spent catalyst. Excess chloroform was removed from the combined filtrate and washings by rotatory evaporation prior to analysis.

\subsection{Liquid Product Analysis}

The liquid products were analyzed using a combined Simulated Distillation-GC and GC-MS method purposely devised to identify and quantify the reactants, intermediates, and products involved in the upgrading of fats and oils to hydrocarbons. Detailed information about the development and application of this method is available elsewhere [67]. The analyses were performed using an Agilent (Santa Clara, CA, USA) 7890B GC system equipped with an Agilent (Santa Clara, CA, USA) 5977A extractor MSD and a flame ionization detector (FID). The multimode inlet, which contained a helix liner, was run in split mode $(15: 1$; split flow, $48 \mathrm{~mL} / \mathrm{min})$ with an initial temperature of $100{ }^{\circ} \mathrm{C}$. He was 
used as the carrier gas and a $1 \mu \mathrm{L}$ injection was employed. Upon injection, the inlet temperature was immediately increased to $380^{\circ} \mathrm{C}$ at a rate of $8{ }^{\circ} \mathrm{C} / \mathrm{min}$, and the temperature was maintained for the course of the analysis. The oven temperature was increased upon injection from $40{ }^{\circ} \mathrm{C}$ to $325{ }^{\circ} \mathrm{C}$ at a rate of $4{ }^{\circ} \mathrm{C} / \mathrm{min}$, followed by a ramp of $10{ }^{\circ} \mathrm{C} / \mathrm{min}$ to $400{ }^{\circ} \mathrm{C}$, which was maintained for $12.5 \mathrm{~min}$. The total analysis run time was $91.25 \mathrm{~min}$. An Agilent (Santa Clara, CA, USA) J\&W VF-5ht column $(30 \mathrm{~m} \times 250 \mu \mathrm{m} \times 0.1 \mu \mathrm{m})$ rated to $450{ }^{\circ} \mathrm{C}$ was used. Column eluents were directed to a Siltek MXT connector that split the flow into two streams, with one leading to the MSD (J\&W Ultimetal Plus Tubing, $11 \mathrm{~m} \times 0.25 \mathrm{~mm}$ i.d.) and one leading to the FID (J\&W Ultimetal Plus Tubing, $5 \mathrm{~m} \times 0.25 \mathrm{~mm}$ i.d.). The MS zone temperatures (MS source at $230{ }^{\circ} \mathrm{C}$ and quadrupole at $150{ }^{\circ} \mathrm{C}$ ) were held constant for the duration of the analysis. A 1.75 min solvent delay was implemented and the MSD scanned from 10 to $700 \mathrm{Da}$. The FID was set to $390{ }^{\circ} \mathrm{C}$ with the following gas flow rates: $\mathrm{H}_{2}=40 \mathrm{~mL} / \mathrm{min}$; air $=400 \mathrm{~mL} / \mathrm{min} ;$ He makeup $=25 \mathrm{~mL} / \mathrm{min}$. Quantification was performed using cyclohexanone as the internal standard. Agilent (Santa Clara, CA, USA) MassHunter Acquisition and SimDis Expert 9-purchased from Separation Systems Inc. (Gulf Breeze, FL, USA)—software packages were respectively used to perform chromatographic programming and to process the GC-FID data acquired. Solvents (i.e., chloroform and dodecane) were quenched and/or subtracted prior to data processing.

\section{Conclusions}

Results of catalyst screening tests in a semi-batch reactor show that $\mathrm{Pt}$ is an effective promoter of supported $\mathrm{Ni}$ catalysts in the deCO of tristearin at $260{ }^{\circ} \mathrm{C}$, with the conversion increasing from $2 \%$ over $20 \% \mathrm{Ni} / \mathrm{Al}_{2} \mathrm{O}_{3}$ to $100 \%$ over $20 \% \mathrm{Ni}-0.5 \% \mathrm{Pt} / \mathrm{Al}_{2} \mathrm{O}_{3}$. In addition, $20 \% \mathrm{Ni}-0.5 \% \mathrm{Pt} / \mathrm{Al}_{2} \mathrm{O}_{3}$ yielded a selectivity to diesel-like hydrocarbons (C10-C17) of $96 \%$ with a $65 \%$ selectivity to $\mathrm{C} 17$, the primary deCO $\mathrm{C}_{\mathrm{x}}$ product. Notably, these improvements in the $\mathrm{deCO}_{x}$ performance result from a synergistic effect of the two metals, as indicated by the fact that $20 \% \mathrm{Ni}-0.5 \% \mathrm{Pt} / \mathrm{Al}_{2} \mathrm{O}_{3}$ displays a conversion significantly higher than the sum of the conversion values afforded by monometallic $20 \% \mathrm{Ni} / \mathrm{Al}_{2} \mathrm{O}_{3}$ and $0.5 \% \mathrm{Pt} / \mathrm{Al}_{2} \mathrm{O}_{3}$ catalysts. Catalyst characterization reveals that the superior activity of Ni-Pt relative to Ni-only catalysts is not a result of Ni particle size effects or surface area differences, but rather stems from several other phenomena, including the improved reducibility of $\mathrm{NiO}$ when $\mathrm{Pt}$ is present. Indeed, $\mathrm{H}_{2}$ pulsed chemisorption measurements identified $2.55 \times 10^{18} / \mathrm{g}$ and $1.72 \times 10^{19} / \mathrm{g}$ adsorption sites on $20 \% \mathrm{Ni} / \mathrm{Al}_{2} \mathrm{O}_{3}$ and $20 \% \mathrm{Ni}-0.5 \% \mathrm{Pt} / \mathrm{Al}_{2} \mathrm{O}_{3}$, respectively. This suggests that the addition of a small amount of $\mathrm{Pt}$ to the supported $\mathrm{Ni}$ catalyst reduced at $350{ }^{\circ} \mathrm{C}$ dramatically increases the amount of reduced surface metal sites, which are believed to be the active sites for deCO $\mathrm{C}_{\mathrm{x}}$ reactions. Moreover, CO-TPD measurements suggest that Pt addition curbs the adsorption of $\mathrm{CO}$ on the catalyst surface, which should decrease catalyst poisoning by any $\mathrm{CO}$ evolved via decarbonylation and make additional active sites available for deoxygenation reactions and/or prevent catalyst coking. Further, $\mathrm{CO}$ adsorption studies coupled with DRIFTS measurements indicate that Pt addition weakens the $\mathrm{Ni}-\mathrm{CO}$ bond and lowers the binding strength of $\mathrm{CO}$ on surface Ni sites. Finally, TGA of the spent catalysts recovered from deCO $\mathrm{C}_{x}$ experiments suggests that the beneficial effect of $\mathrm{Pt}$ on catalyst performance can also be explained by decreased coking and fouling. The majority of the surface deposits observed corresponded to strongly adsorbed reactants, intermediates, and products (or soft coke), as only a small amount of hard coke was detected. The ability of $\mathrm{Pt}$ to chemisorb $\mathrm{H}_{2}$ and facilitate $\mathrm{H}$ migration across the surface of the catalyst presumably helps remove these adspecies via hydrogenation, which explains the inverse relationship between Pt loading and the extent of coking and fouling.

Author Contributions: Individual contributions are as follows: conceptualization, E.S.-J. and M.C.; methodology, R.L., E.S.-J., and M.C.; software, M.W.; validation, R.L., K.H., and M.W.; formal analysis, R.L., R.P., D.Q., M.I., and T.M.; investigation, R.L., T.M., K.H., and M.W.; resources, E.S.-J. and M.C.; data curation, R.L. and Y.S.; writing-original draft preparation, R.L.; writing-review and editing, E.S.-J. and M.C.; visualization, R.L.; supervision, R.L., E.S.-J., and M.C.; project administration, E.S.-J. and M.C.; funding acquisition, E.S.-J. and M.C. 
Funding: This work was supported in part by the National Science Foundation (NSF) under grant Nos. 1437604, 1531637, and 1444779, as well as by a Research Support Grant from the University of Kentucky Office of the Vice President for Research and a Grant from the University of Kentucky Student Sustainability Council.

Conflicts of Interest: The authors declare no conflict of interest. The funders had no role in the design of the study; in the collection, analyses, or interpretation of data; in the writing of the manuscript, or in the decision to publish the results.

\section{Appendix A}
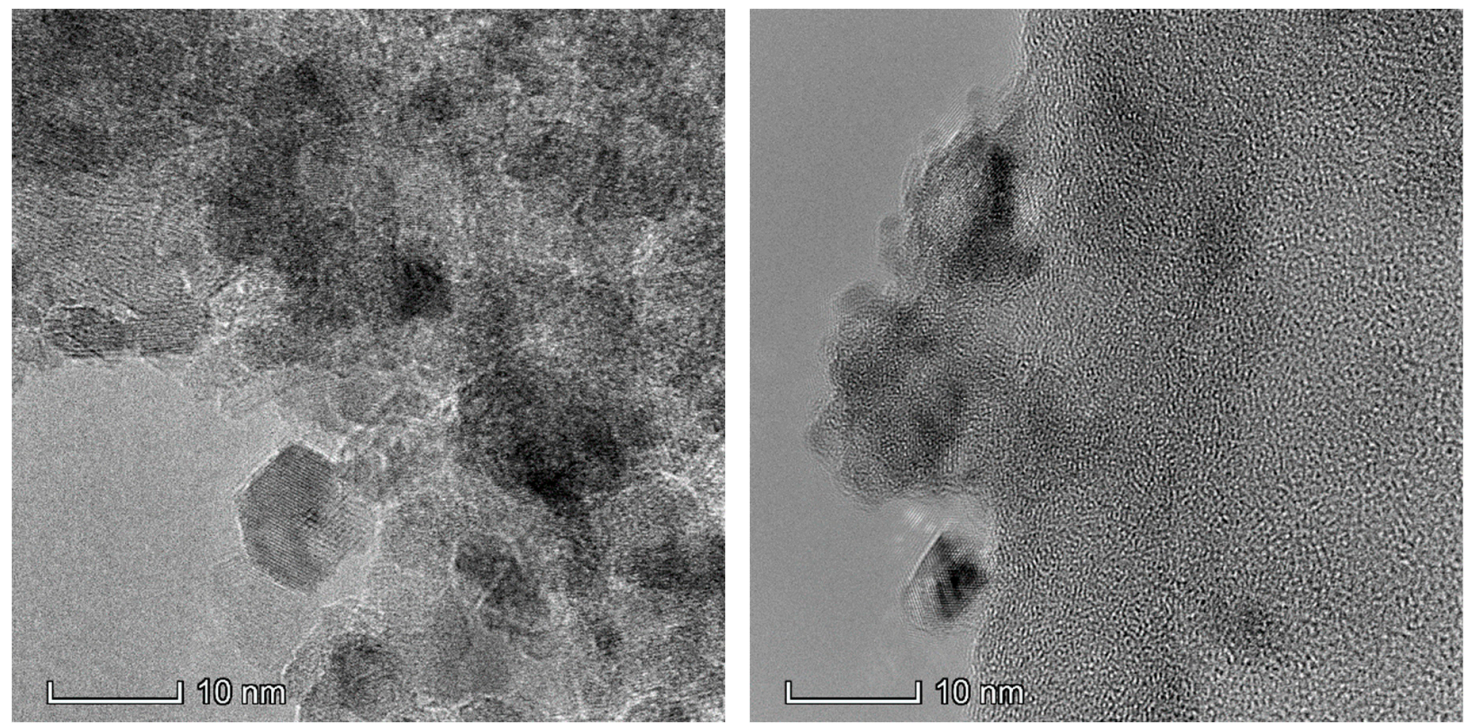

Figure A1. TEM micrographs of $20 \% \mathrm{Ni} / \mathrm{Al}_{2} \mathrm{O}_{3}$ (left) and $20 \% \mathrm{Ni}-0.5 \% \mathrm{Pt} / \mathrm{Al}_{2} \mathrm{O}_{3}$ (right) showing the similar metal particle size of the monometallic and bimetallic formulations.
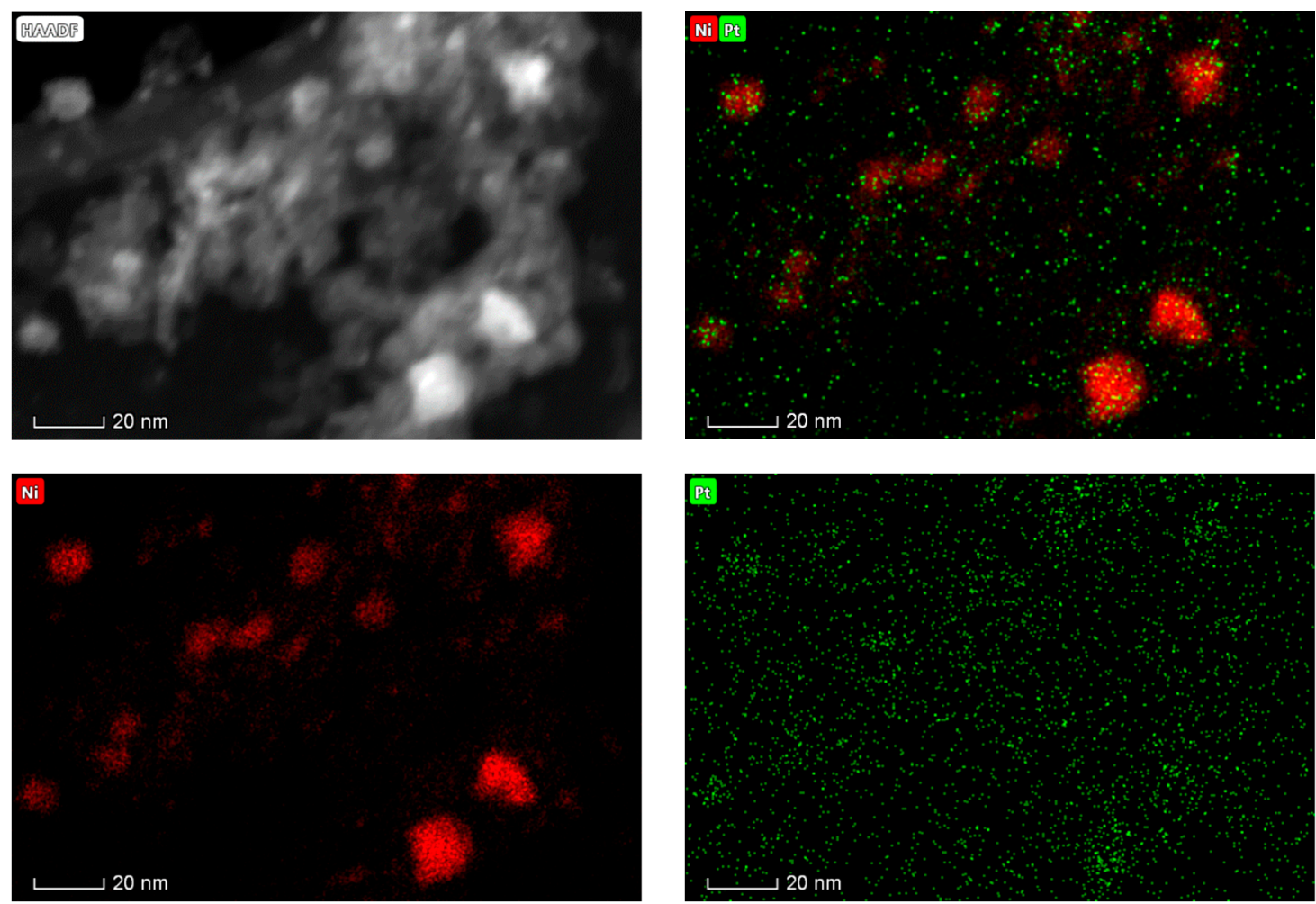

Figure A2. High-angle annular dark-field (HAADF) scanning transmission electron micrograph (top left) of a region within the $20 \% \mathrm{Ni}-0.5 \% \mathrm{Pt} / \mathrm{Al}_{2} \mathrm{O}_{3}$ catalyst and the corresponding elemental maps of both $\mathrm{Ni}$ and $\mathrm{Pt}$ (top right), Ni only (bottom left), and Pt only (bottom right). 


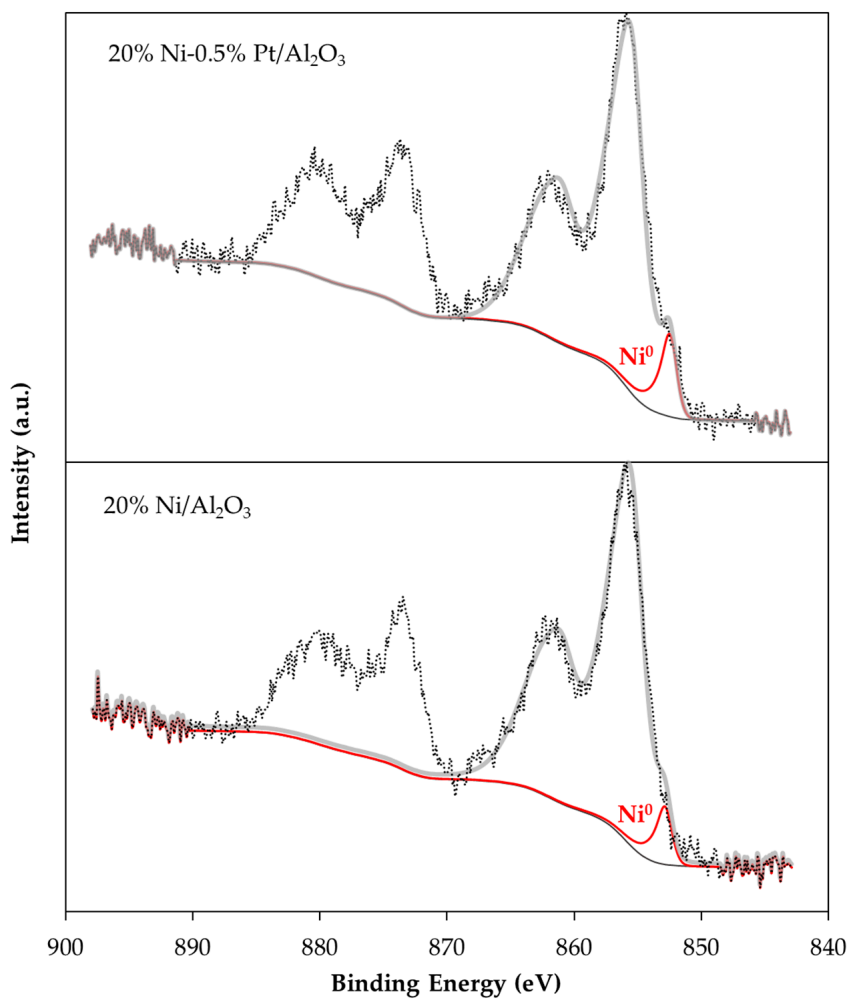

Figure A3. Nickel 2p X-ray photoelectron spectra of $20 \% \mathrm{Ni} / \mathrm{Al}_{2} \mathrm{O}_{3}$ and $20 \% \mathrm{Ni}-0.5 \% \mathrm{Pt} / \mathrm{Al}_{2} \mathrm{O}_{3}$ after reduction under $\mathrm{H}_{2}$ at $400{ }^{\circ} \mathrm{C}$.
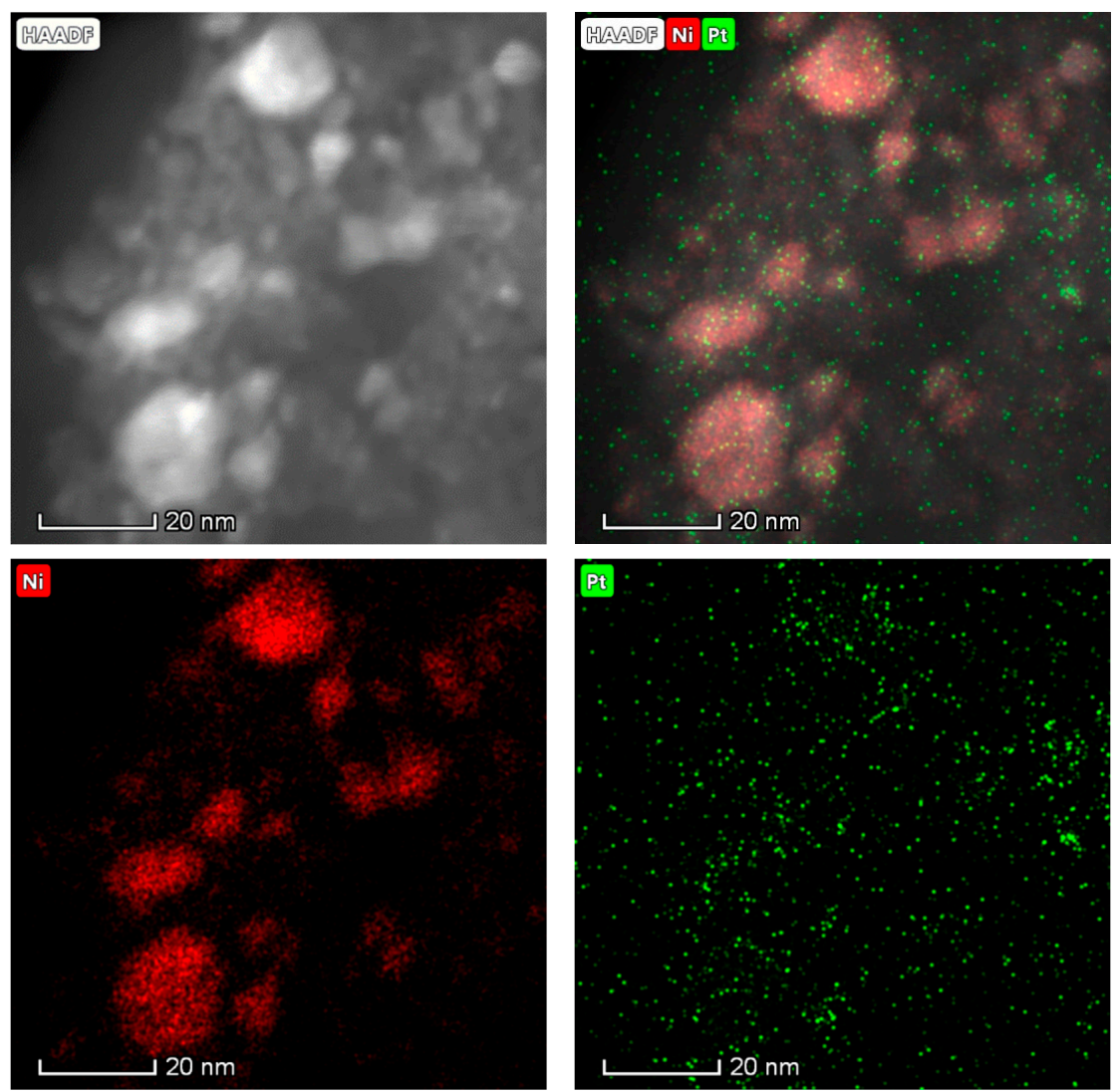

Figure A4. High-angle annular dark-field (HAADF) scanning transmission electron micrograph (top left) of a region within the spent $20 \% \mathrm{Ni}-0.5 \% \mathrm{Pt} / \mathrm{Al}_{2} \mathrm{O}_{3}$ catalyst and the corresponding elemental maps of both $\mathrm{Ni}$ and $\mathrm{Pt}$ (top right), Ni only (bottom left), and Pt only (bottom right). 


\section{References}

1. Fargione, J.; Hill, J.; Tilman, D.; Polasky, S.; Hawthorne, P. Land clearing and the biofuel carbon debt. Science 2008, 319, 1235-1238. [CrossRef] [PubMed]

2. Tilman, D.; Hill, J.; Lehman, C. Carbon-negative biofuels from low-input high-diversity grassland biomass. Science 2006, 314, 1598-1600. [CrossRef] [PubMed]

3. Berenblyum, A.S.; Podoplelova, T.A.; Shamsiev, R.S.; Katsman, E.A.; Danyushevsky, V.Y.; Flid, V.R. Catalytic chemistry of preparation of hydrocarbon fuels from vegetable oils and fats. Catal. Ind. 2012, 4, $209-214$. [CrossRef]

4. Benazzi, E.; Cameron, C. Boutique diesel in the on-road market. Hydrocarbon Process. 2006, 85, DD17-DD18.

5. Kubičková, I.; Snåre, M.; Eränen, K.; Mäki-Arvela, P.; Murzin, D.Y. Hydrocarbons for diesel fuel via decarboxylation of vegetable oils. Catal. Today 2005, 106, 197-200. [CrossRef]

6. Kordulis, C.; Bourikas, K.; Gousi, M.; Kordouli, E.; Lycourghiotis, A. Development of nickel based catalysts for the transformation of natural triglycerides and related compounds into green diesel: A critical review. Appl. Catal. B 2016, 181, 156-196. [CrossRef]

7. Santillan-Jimenez, E.; Crocker, M. Catalytic deoxygenation of fatty acids and their derivatives to hydrocarbon fuels via decarboxylation/decarbonylation. J. Chem. Technol. Biotechnol. 2012, 87, 1041-1050. [CrossRef]

8. Snåre, M.; Kubičková, I.; Mäki-Arvela, P.; Eränen, K.; Murzin, D.Y. Heterogeneous catalytic deoxygenation of stearic acid for production of biodiesel. Ind. Eng. Chem. Res. 2006, 45, 5708-5715. [CrossRef]

9. Mäki-Arvela, P.; Kubickova, I.; Snåre, M.; Eränen, K.; Murzin, D.Y. Catalytic deoxygenation of fatty acids and their derivatives. Energy Fuels 2007, 21, 30-41. [CrossRef]

10. Snåre, M.; Kubicková, I.; Mäki-Arvela, P.; Chichova, D.; Eränen, K.; Murzin, D.Y. Catalytic deoxygenation of unsaturated renewable feedstocks for production of diesel fuel hydrocarbons. Fuel 2008, 87, $933-945$. [CrossRef]

11. Simakova, I.; Simakova, O.; Mäki-Arvela, P.; Murzin, D.Y. Decarboxylation of fatty acids over Pd supported on mesoporous carbon. Catal. Today 2010, 150, 28-31. [CrossRef]

12. Simakova, I.; Rozmysłowicz, B.; Simakova, O.; Mäki-Arvela, P.; Simakov, A.; Murzin, D.Y. Catalytic Deoxygenation of C18 Fatty Acids Over Mesoporous Pd/C Catalyst for Synthesis of Biofuels. Top. Catal. 2011, 54, 460-466. [CrossRef]

13. Immer, J.G.; Lamb, H.H. Fed-batch catalytic deoxygenation of free fatty acids. Energy Fuels 2010, 24, 5291-5299. [CrossRef]

14. Immer, J.G.; Kelly, M.J.; Lamb, H.H. Catalytic reaction pathways in liquid-phase deoxygenation of C18 free fatty acids. Appl. Catal. A 2010, 375, 134-139. [CrossRef]

15. Hengst, K.; Arend, M.; Pfützenreuter, R.; Hoelderich, W.F. Deoxygenation and cracking of free fatty acids over acidic catalysts by single step conversion for the production of diesel fuel and fuel blends. Appl. Catal. B 2015, 174-175, 383-394. [CrossRef]

16. Sari, E.; DiMaggio, C.; Kim, M.; Salley, S.O.; Ng, K.Y.S. Catalytic conversion of brown grease to green diesel via decarboxylation over activated carbon supported palladium catalyst. Ind. Eng. Chem. Res. 2013, 52, 11527-11536. [CrossRef]

17. de Sousa, F.P.; Cardoso, C.C.; Pasa, V.M. Producing hydrocarbons for green diesel and jet fuel formulation from palm kernel fat over Pd/C. Fuel Process. Technol. 2016, 143, 35-42. [CrossRef]

18. Shao, Y.; Xia, Q.; Liu, X.; Lu, G.; Wang, Y. Pd $/ \mathrm{Nb}_{2} \mathrm{O}_{5} / \mathrm{SiO}_{2}$ Catalyst for the Direct Hydrodeoxygenation of Biomass-Related Compounds to Liquid Alkanes under Mild Conditions. ChemSusChem 2015, 8, 1761-1767. [CrossRef] [PubMed]

19. Do, P.T.; Chiappero, M.; Lobban, L.L.; Resasco, D.E. Catalytic deoxygenation of methyl-octanoate and methyl-stearate on $\mathrm{Pt} / \mathrm{Al}_{2} \mathrm{O}_{3}$. Catal. Lett. 2009, 130, 9-18. [CrossRef]

20. Chiappero, M.; Do, P.T.M.; Crossley, S.; Lobban, L.L.; Resasco, D.E. Direct conversion of triglycerides to olefins and paraffins over noble metal supported catalysts. Fuel 2011, 90, 1155-1165. [CrossRef]

21. Na, J.-G.; Yi, B.E.; Han, J.K.; Oh, Y.-K.; Park, J.-H.; Jung, T.S.; Han, S.S.; Yoon, H.C.; Kim, J.-N.; Lee, H.; et al. Deoxygenation of microalgal oil into hydrocarbon with precious metal catalysts: Optimization of reaction conditions and supports. Energy 2012, 47, 25-30. [CrossRef]

22. Fu, J.; Lu, X.; Savage, P.E. Hydrothermal decarboxylation and hydrogenation of fatty acids over Pt/C. ChemSusChem 2011, 4, 481-486. [CrossRef] [PubMed] 
23. Yang, L.; Carreon, M.A. Deoxygenation of palmitic and lauric acids over Pt/ZIF-67 membrane/zeolite 5A bead catalysts. ACS Appl. Mater. Int. 2017, 9, 31993-32000. [CrossRef] [PubMed]

24. Ahmadi, M.; Nambo, A.; Jasinski, J.B.; Ratnasamy, P.; Carreon, M.A. Decarboxylation of oleic acid over Pt catalysts supported on small-pore zeolites and hydrotalcite. Catal. Sci. Technol. 2015, 5, 380-388. [CrossRef]

25. Ahmadi, M.; Macias, E.E.; Jasinski, J.B.; Ratnasamy, P.; Carreon, M.A. Decarboxylation and further transformation of oleic acid over bifunctional, Pt/SAPO-11 catalyst and Pt/chloride $\mathrm{Al}_{2} \mathrm{O}_{3}$ catalysts. J. Mol. Catal. A Chem. 2014, 386, 14-19. [CrossRef]

26. Tian, Q.; Qiao, K.; Zhou, F.; Chen, K.; Wang, T.; Fu, J.; Lu, X.; Ouyang, P. Direct production of aviation fuel range hydrocarbons and aromatics from oleic acid without an added hydrogen donor. Energy Fuels 2016, 30, 7291-7297. [CrossRef]

27. Kon, K.; Onodera, W.; Takakusagi, S.; Shimizu, K.-i. Hydrodeoxygenation of fatty acids and triglycerides by Pt-loaded $\mathrm{Nb}_{2} \mathrm{O}_{5}$ catalysts. Catal. Sci. Technol. 2014, 4, 3705-3712. [CrossRef]

28. Kon, K.; Toyao, T.; Onodera, W.; Siddiki, S.M.A.H.; Shimizu, K.-i. Hydrodeoxygenation of Fatty Acids, Triglycerides, and Ketones to Liquid Alkanes by a Pt-MoOx $/ \mathrm{TiO}_{2}$ Catalyst. ChemCatChem 2017, 9, $2822-2827$. [CrossRef]

29. Janampelli, S.; Darbha, S. Metal Oxide-Promoted Hydrodeoxygenation Activity of Platinum in $\mathrm{Pt}-\mathrm{MO}_{\mathrm{x}} / \mathrm{Al}_{2} \mathrm{O}_{3}$ Catalysts for Green Diesel Production. Energy Fuels 2018, 32, 12630-12643. [CrossRef]

30. Morgan, T.; Grubb, D.; Santillan-Jimenez, E.; Crocker, M. Conversion of triglycerides to hydrocarbons over supported metal catalysts. Top. Catal. 2010, 53, 820-829. [CrossRef]

31. Santillan-Jimenez, E.; Morgan, T.; Lacny, J.; Mohapatra, S.; Crocker, M. Catalytic deoxygenation of triglycerides and fatty acids to hydrocarbons over carbon-supported nickel. Fuel 2013, 103, 1010-1017. [CrossRef]

32. Loe, R.; Santillan-Jimenez, E.; Morgan, T.; Sewell, L.; Ji, Y.; Jones, S.; Isaacs, M.A.; Lee, A.F.; Crocker, M. Effect of $\mathrm{Cu}$ and $\mathrm{Sn}$ promotion on the catalytic deoxygenation of model and algal lipids to fuel-like hydrocarbons over supported Ni catalysts. Appl. Catal. B 2016, 191, 147-156. [CrossRef]

33. Santillan-Jimenez, E.; Morgan, T.; Shoup, J.; Harman-Ware, A.E.; Crocker, M. Catalytic deoxygenation of triglycerides and fatty acids to hydrocarbons over Ni-Al layered double hydroxide. Catal. Today 2014, 237, 136-144. [CrossRef]

34. Santillan-Jimenez, E.; Morgan, T.; Loe, R.; Crocker, M. Continuous catalytic deoxygenation of model and algal lipids to fuel-like hydrocarbons over Ni-Al layered double hydroxide. Catal. Today 2015, 258, $284-293$. [CrossRef]

35. Morgan, T.; Santillan-Jimenez, E.; Harman-Ware, A.E.; Ji, Y.; Grubb, D.; Crocker, M. Catalytic deoxygenation of triglycerides to hydrocarbons over supported nickel catalysts. Chem. Eng. J. 2012, 189-190, 346-355. [CrossRef]

36. Peng, B.; Zhao, C.; Kasakov, S.; Foraita, S.; Lercher, J.A. Manipulating catalytic pathways: Deoxygenation of palmitic acid on multifunctional catalysts. Chem. Eur. J. 2013, 19, 4732-4741. [CrossRef] [PubMed]

37. Peng, B.; Yuan, X.; Zhao, C.; Lercher, J.A. Stabilizing catalytic pathways via redundancy: Selective reduction of microalgae oil to alkanes. J. Am. Chem. Soc. 2012, 134, 9400-9405. [CrossRef]

38. Peng, B.; Yao, Y.; Zhao, C.; Lercher, J.A. Towards quantitative conversion of microalgae oil to diesel-range alkanes with bifunctional catalysts. Angew. Chem. 2012, 124, 2114-2117. [CrossRef]

39. Ford, J.P.; Immer, J.G.; Lamb, H.H. Palladium catalysts for fatty acid deoxygenation: Influence of the support and fatty acid chain length on decarboxylation kinetics. Top. Catal. 2012, 55, 175-184. [CrossRef]

40. Hollak, S.A.W.; de Jong, K.P.; van Es, D.S. Catalytic deoxygenation of fatty acids: Elucidation of the inhibition process. ChemCatChem 2014, 6, 2648-2655. [CrossRef]

41. Song, W.; Zhao, C.; Lercher, J.A. Importance of size and distribution of Ni nanoparticles for the hydrodeoxygenation of microalgae oil. Chem. Eur. J. 2013, 19, 9833-9842. [CrossRef] [PubMed]

42. Santillan-Jimenez, E.; Loe, R.; Garrett, M.; Morgan, T.; Crocker, M. Effect of Cu promotion on cracking and methanation during the Ni-catalyzed deoxygenation of waste lipids and hemp seed oil to fuel-like hydrocarbons. Catal. Today 2018, 302, 261-271. [CrossRef]

43. Guo, Q.; Wu, M.; Wang, K.; Zhang, L.; Xu, X. Catalytic Hydrodeoxygenation of Algae Bio-oil over Bimetallic $\mathrm{Ni}-\mathrm{Cu} / \mathrm{ZrO}_{2}$ Catalysts. Ind. Eng. Chem. Res. 2015, 54, 890-899. [CrossRef]

44. Pan, Z.; Wang, R.; Nie, Z.; Chen, J. Effect of a second metal (Co, Fe, Mo and W) on performance of $\mathrm{Ni}_{2} \mathrm{P} / \mathrm{SiO}_{2}$ for hydrodeoxygenation of methyl laurate. J. Energy Chem. 2016, 25, 418-426. [CrossRef] 
45. Shi, Y.; Xing, E.; Cao, Y.; Liu, M.; Wu, K.; Yang, M.; Wu, Y. Tailoring product distribution during upgrading of palmitic acid over bi-functional metal/zeolite catalysts. Chem. Eng. Sci. 2017, 166, 262-273. [CrossRef]

46. Chen, H.; Zhang, X.; Zhang, J.; Wang, Q. Tuning Decarboxylation Selectivity for Deoxygenation of Vegetable Oil over Pt-Ni Bimetal Catalysts via Surface Engineering. Catal. Sci. Technol. 2018. [CrossRef]

47. Li, X.-F.; Luo, X.-G. Preparation of mesoporous activated carbon supported Ni catalyst for deoxygenation of stearic acid into hydrocarbons. Environ. Prog. Sustain. Energy 2015, 34, 607-612. [CrossRef]

48. Lu, S.; Lonergan, W.W.; Bosco, J.P.; Wang, S.; Zhu, Y.; Xie, Y.; Chen, J.G. Low temperature hydrogenation of benzene and cyclohexene: A comparative study between $\gamma-\mathrm{Al}_{2} \mathrm{O}_{3}$ supported PtCo and PtNi bimetallic catalysts. J. Catal. 2008, 259, 260-268. [CrossRef]

49. Tanksale, A.; Beltramini, J.; Dumesic, J.; Lu, G. Effect of Pt and Pd promoter on Ni supported catalysts-A TPR/TPO/TPD and microcalorimetry study. J. Catal. 2008, 258, 366-377. [CrossRef]

50. Vizcaíno, A.; Carrero, A.; Calles, J. Hydrogen production by ethanol steam reforming over Cu-Ni supported catalysts. Int. J. Hydrogen Energy 2007, 32, 1450-1461. [CrossRef]

51. Rynkowski, J.M.; Paryjczak, T.; Lenik, M. On the nature of oxidic nickel phases in $\mathrm{NiO} / \gamma-\mathrm{Al}_{2} \mathrm{O}_{3}$ catalysts. Appl. Catal. A 1993, 106, 73-82. [CrossRef]

52. Ko, E.-Y.; Park, E.D.; Seo, K.W.; Lee, H.C.; Lee, D.; Kim, S. Pt-Ni $/ \gamma-\mathrm{Al}_{2} \mathrm{O}_{3}$ catalyst for the preferential CO oxidation in the hydrogen stream. Catal. Lett. 2006, 110, 275-279. [CrossRef]

53. Jackson, S.; Glanville, B.; Willis, J.; McLellan, G.; Webb, G.; Moyes, R.; Simpson, S.; Wells, P.; Whyman, R. Supported metal catalysts: Preparation, characterization, and function: II. Carbon monoxide and dioxygen adsorption on platinum catalysts. J. Catal. 1993, 139, 207-220. [CrossRef]

54. Dias, J.A.; Assaf, J.M. Autothermal reforming of methane over $\mathrm{Ni} / \gamma-\mathrm{Al}_{2} \mathrm{O}_{3}$ catalysts: The enhancement effect of small quantities of noble metals. J. Power Sources 2004, 130, 106-110. [CrossRef]

55. Parizotto, N.; Zanchet, D.; Rocha, K.; Marques, C.; Bueno, J. The effects of Pt promotion on the oxi-reduction properties of alumina supported nickel catalysts for oxidative steam-reforming of methane: Temperature-resolved XAFS analysis. Appl. Catal. A 2009, 366, 122-129. [CrossRef]

56. Riguetto, B.A.; Damyanova, S.; Gouliev, G.; Marques, C.M.; Petrov, L.; Bueno, J.M.C. Surface behavior of alumina-supported $\mathrm{Pt}$ catalysts modified with cerium as revealed by $\mathrm{X}$-ray diffraction, $\mathrm{X}$-ray photoelectron spectroscopy, and Fourier transform infrared spectroscopy of CO adsorption. J. Phys. Chem. B 2004, 108, 5349-5358. [CrossRef]

57. Xu, J.; White, T.; Li, P.; He, C.; Yu, J.; Yuan, W.; Han, Y.-F. Biphasic Pd-Au alloy catalyst for low-temperature CO oxidation. J. Am. Chem. Soc. 2010, 132, 10398-10406. [CrossRef]

58. Fisk, C.A.; Morgan, T.; Ji, Y.; Crocker, M.; Crofcheck, C.; Lewis, S.A. Bio-oil upgrading over platinum catalysts using in situ generated hydrogen. Appl. Catal. A 2009, 358, 150-156. [CrossRef]

59. Sugami, Y.; Minami, E.; Saka, S. Renewable diesel production from rapeseed oil with hydrothermal hydrogenation and subsequent decarboxylation. Fuel 2016, 166, 376-381. [CrossRef]

60. Huber, G.W.; O'Connor, P.; Corma, A. Processing biomass in conventional oil refineries: Production of high quality diesel by hydrotreating vegetable oils in heavy vacuum oil mixtures. Appl. Catal. A 2007, 329, 120-129. [CrossRef]

61. Berenblyum, A.S.; Danyushevsky, V.Y.; Katsman, E.A.; Podoplelova, T.A.; Flid, V.R. Production of engine fuels from inedible vegetable oils and fats. Pet. Chem. 2010, 50, 305-311. [CrossRef]

62. Kikhtyanin, O.V.; Rubanov, A.E.; Ayupov, A.B.; Echevsky, G.V. Hydroconversion of sunflower oil on Pd/SAPO-31 catalyst. Fuel 2010, 89, 3085-3092. [CrossRef]

63. Zhang, H.; Shao, S.; Xiao, R.; Shen, D.; Zeng, J. Characterization of coke deposition in the catalytic fast pyrolysis of biomass derivates. Energy Fuels 2013, 28, 52-57. [CrossRef]

64. Chen, L.; Li, H.; Fu, J.; Miao, C.; Lv, P.; Yuan, Z. Catalytic hydroprocessing of fatty acid methyl esters to renewable alkane fuels over Ni/HZSM-5 catalyst. Catal. Today 2016, 259, 266-276. [CrossRef]

65. Loe, R.; Lavoignat, Y.; Maier, M.; Abdallah, M.; Morgan, T.; Qian, D.; Pace, R.; Santillan-Jimenez, E.; Crocker, M. Continuous Catalytic Deoxygenation of Waste Free Fatty Acid-Based Feeds to Fuel-Like Hydrocarbons Over a Supported Ni-Cu Catalyst. Catalysts 2019, 9, 123. [CrossRef] 
66. Grosvenor, A.P.; Biesinger, M.C.; Smart, R.S.C.; McIntyre, N.S. New interpretations of XPS spectra of nickel metal and oxides. Surf. Sci. 2006, 600, 1771-1779. [CrossRef]

67. Morgan, T.; Santillan-Jimenez, E.; Huff, K.; Javed, K.R.; Crocker, M. Use of dual detection in the gas chromatographic analysis of oleaginous biomass feeds and biofuel products to enable accurate simulated distillation and lipid profiling. Energy Fuels 2017, 31, 9498-9506. [CrossRef] 